\title{
SURFICIAL GEOLOGIC MAP OF PARTS OF THE ILIAMNA D-6 AND D-7 QUADRANGLES, PEBBLE PROJECT AREA, SOUTHWESTERN ALASKA
}

by

T. D. Hamilton and R.F. Klieforth

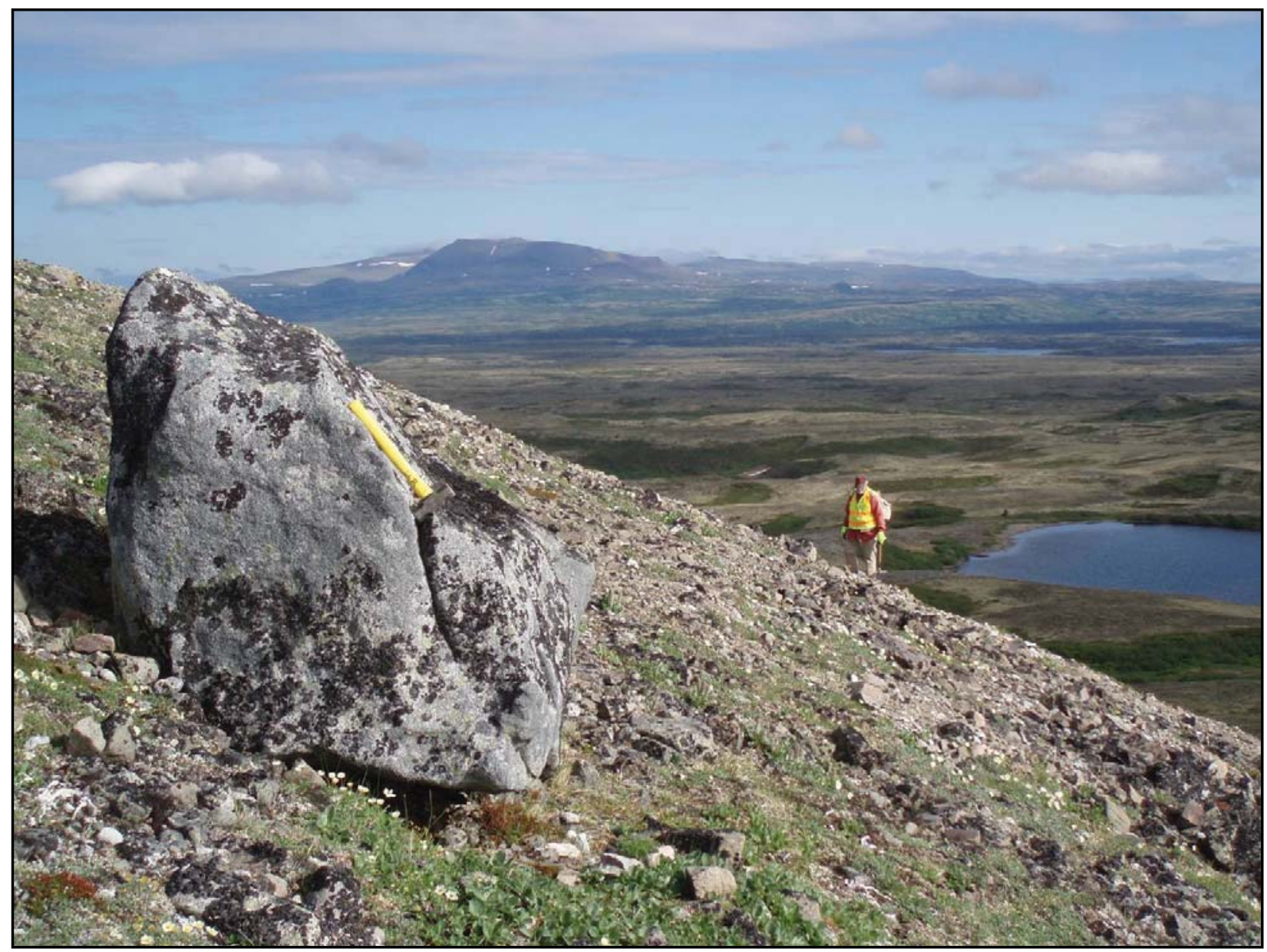

Typical features of map area. Isolated mountain block (background), drift-filled lowland (middle distance), and erratic boulders on mountain flanks (foreground).

\section{Published by}

STATE OF ALASKA

DEPARTMENT OF NATURAL RESOURCES

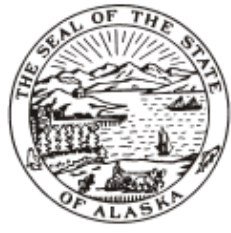

DIVISION OF GEOLOGICAL \& GEOPHYSICAL SURVEYS

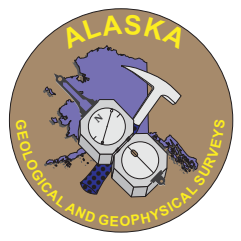





\section{Report of Investigations 2009-4}

\section{SURFICIAL GEOLOGIC MAP OF PARTS OF THE ILIAMNA D-6 AND D-7 QUADRANGLES, PEBBLE PROJECT AREA, SOUTHWESTERN ALASKA}

by

T.D. Hamilton and R.F. Klieforth

2010

THIS GEOLOGIC INVESTIGATION WAS COMMISSIONED

and funded by the Pebble Limited Partnership.

Costs to publish this RePort were Paid by the State of Alaska.

This DGGS Report of Investigations is a final report of scientific research. It has received technical review and may be cited as an agency publication.

Nothing appearing in this publication should be taken as an endorsement of any product or company by the State of Alaska or any of its representatives. 


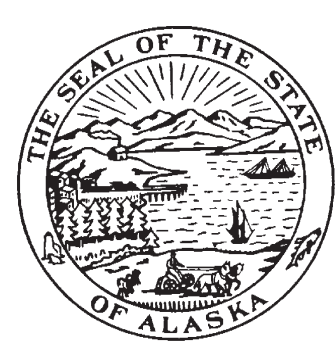

STATE OF ALASKA

Sean Parnell, Governor

DEPARTMENT OF NATURAL RESOURCES

Tom Irwin, Commissioner

DIVISION OF GEOLOGICAL \& GEOPHYSICAL SURVEYS

Robert F. Swenson, State Geologist

Rodney A. Combellick, Acting Director

Publications produced by the Division of Geological \& Geophysical Surveys can be examined at the following locations. To order publications, contact the Fairbanks office.

\section{Alaska Division of Geological \& Geophysical Surveys \\ 3354 College Rd., Fairbanks, Alaska 99709-3707 \\ Phone: (907) 451-5020 Fax (907) 451-5050 \\ dggspubs@alaska.gov \\ www.dggs.alaska.gov}

Alaska State Library

State Office Building, 8th Floor

3354 College Road

Juneau, Alaska 99811-0571

Elmer E. Rasmuson Library University of Alaska Fairbanks

Fairbanks, Alaska 99775-1005
Alaska Resource Library \& Information Services (ARLIS)

3150 C Street, Suite 100

Anchorage, Alaska 99503

University of Alaska Anchorage Library

3211 Providence Drive

Anchorage, Alaska 99508

This publication released by the Division of Geological \& Geophysical Surveys was produced and printed in Fairbanks, Alaska, at a cost of \$15 per copy. Publication is authorized by Alaska Statute 41, which charges the division "to determine the potential of Alaskan land for production of metals, minerals, fuels, and geothermal resources; the location and supplies of groundwater and construction materials; the potential geologic hazards to buildings, roads, bridges, and other installations and structures; and shall conduct such other surveys and investigations as will advance knowledge of the geology of Alaska.” 


\section{CONTENTS}

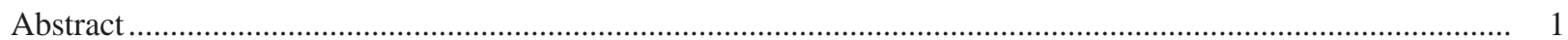

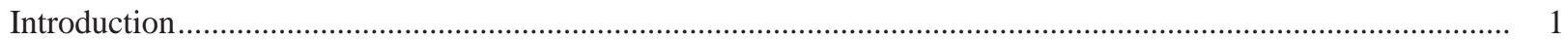

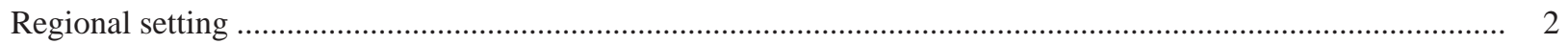

Local geographic setting and nomenclature ............................................................................................... 2

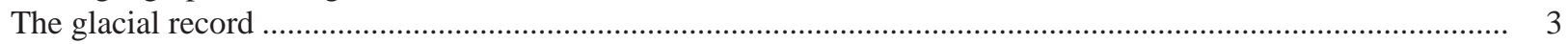

Glacier distribution and flow patterns ......................................................................................................

Glacial sequence, correlations, and inferred chronology …….......................................................................... 5

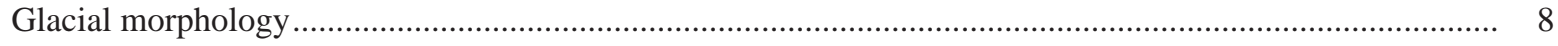

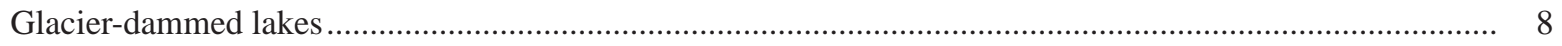

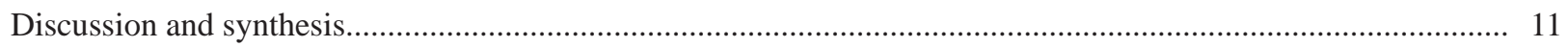

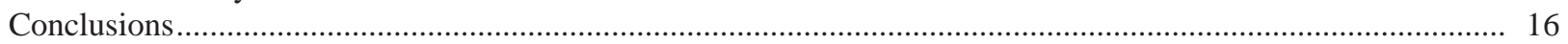

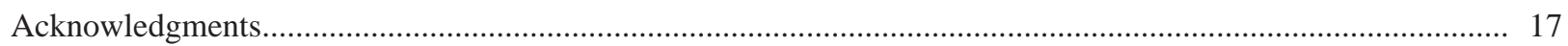

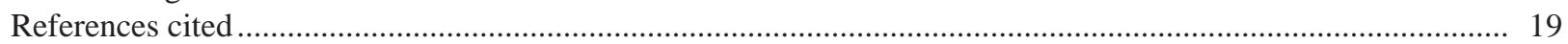

\section{FIGURES}

Figure 1. Map area, showing relations to Iliamna Lake, Cook Inlet, and modern glaciers of Alaska and the Kenai Peninsula.....

2. Map area, showing topographic features, drainages, and Pebble claim block

3. Satellite image of tope

4. Terrain features typical of map area: Groundhog Mountain block and lake-filled Wiggly Lake basin.. 4

5. Principal end moraines deposited by glaciers of middle to late Pleistocene age..................................... 5

6. Glacial deposits of pre-Brooks Lake age on Kaskanak Mountain block................................................. 6

7. Two views of gabbro bedrock outcrop on Kaskanak Mountain block .................................................... 7

8. Glacial deposits of Pebble Project area.................................................................................................. 9

9. Outwash of Kvichak stade age on South Fork of Koktuli River .......................................................... 10

10. Abandoned ice-marginal meltwater channel on south flank of Groundhog Mountain block................. 11

11. Characteristic features of ancient glacial lakes in Pebble project area............................................... 12

12. Inferred distribution in map area of glaciers, outwash, and glacial lakes during pre-Brooks

Lake glaciation(s).

13. Distribution of glaciers and related features during Kvichak stade of Brooks Lake glaciation............ 15

14. Distribution of glaciers and related features during Iliamna stade of Brooks Lake glaciation.............. 16

15. Distribution of glaciers and related features during Newhalen stade of Brooks Lake glaciation........... 17

16. Features indicative of high-magnitude outburst floods east of Upper Talarik Creek ............................ 18

\section{SHEET}

Sheet 1. Surficial geologic map of parts of the Iliamna D-6 and D-7 quadrangles, Pebble project area, southwestern Alaska 



\title{
SURFICIAL GEOLOGIC MAP OF PARTS OF THE ILIAMNA D-6 AND D-7 QUADRANGLES, PEBBLE PROJECT AREA, SOUTHWESTERN ALASKA
}

\author{
by \\ Thomas D. Hamilton ${ }^{1}$ and Robert F. Klieforth ${ }^{2}$
}

\begin{abstract}
The map area was impacted by Pleistocene-age glaciers derived from two principal sources. Glacier ice flowed southwestward down the Lake Clark structural trough, then split into separate ice tongues that penetrated the map area from the north and northeast. A second major ice body probably overflowed westward from Cook Inlet, filling Iliamna Lake basin and expanding into southern parts of the map area. At various times, these glaciers blocked each of the major drainages in the map area, creating ice-dammed lakes. These former lakes are indicated by broad expanses of unusually smooth, poorly drained, and gently sloping terrain that terminate abruptly upslope at consistent altitudes and are commonly bordered by wavecut notches and by beach and deltaic deposits.

At least four episodes of glaciation are recognized in the map area. The oldest is marked by ice-abraded uplands with thin patches of drift and by a conspicuous moraine in the southwestern corner of the map area. The younger three glacial advances correspond to the three oldest stades of the Brooks Lake glaciation, which Detterman and Reed (1973) equate with the late Wisconsin glacial substage of the North American glacial succession. This interval is dated at about 26,000 to 10,000 radiocarbon years before present $\left({ }^{14} \mathrm{C}\right.$ yr BP) elsewhere on the Alaska Peninsula (Stilwell and Kaufman, 1996) and in the upper Cook Inlet region (Reger and Pinney, 1997). During each of the two oldest stades, termed Kvichak and Iliamna by Detterman and Reed (1973), glaciers filled the Lake Clark trough and coalesced with the much larger glacial lobe that filled the basin of Iliamna Lake. Glaciers entered the map area from both north and south at those times. During the subsequent Newhalen stade, glaciers extended only short distances southwest and south of Lake Clark; they penetrated only the extreme northeastern corner and east-central margin of the map area. Meltwater from the Newhalen glacier was deflected southwestward through eastern parts of the map area, possibly because of blockage by persisting glacier ice in Iliamna Lake basin. Broadly limiting dates elsewhere in south-central Alaska indicate that Newhalen stade glaciation may have occurred about 14,000 to $13,500{ }^{14} \mathrm{C}$ yr $\mathrm{BP}$ and that final meltout of stagnating glacier ice in the map area probably was complete by $10,000{ }^{14} \mathrm{C}$ yr BP.
\end{abstract}

\section{INTRODUCTION}

The area covered by the accompanying surficial geologic map (sheet 1 ) is located on the Alaska Peninsula about $320 \mathrm{~km}$ southwest of Anchorage (fig. 1). This area includes nearly all of the claim block owned by the Pebble Limited Partnership and extends for several miles beyond its eastern and northern boundaries (fig. 2). The map area has been strongly affected by late Pleistocene glaciation. Only very small cirque glaciers were generated within its boundaries, but much larger glaciers repeatedly invaded from the north, east, and south. These glaciers blocked drainages, forming glacial lakes and causing probable drainage reversals. During warming episodes that followed glacial advances, the melting glaciers tended to stagnate, downwaste, and disintegrate in place rather than retreat while remaining active. This downwasting led to massive outpourings of glacial meltwater that eroded steep-sided channels that today are abandoned or carry only very small (underfit) streams.

This map and accompanying report are based on airphoto interpretation and examination of drill-hole, test-pit, and hydrologic data generated by environmental consultants to the Pebble Limited Partnership, owner of the Pebble property. Subsequent helicopter-supported field examination of surficial deposits utilized additional shallow auger borings and test pits where required. Following fieldwork, we examined large-scale airphotos to refine map-unit contacts and identify small units and features that were not investigated in the field. This map and report are intended to (1) depict and illustrate the unconsolidated deposits present at and very close to the surface of the study area, (2) explain the origin of those deposits, and (3) reconstruct the sequence of events by which they formed.

13918 Wesleyan Drive, Anchorage, Alaska 99508

${ }^{2}$ SLR International Corporation, 4601 Business Park Boulevard, Suite K42, Anchorage, Alaska 99503 


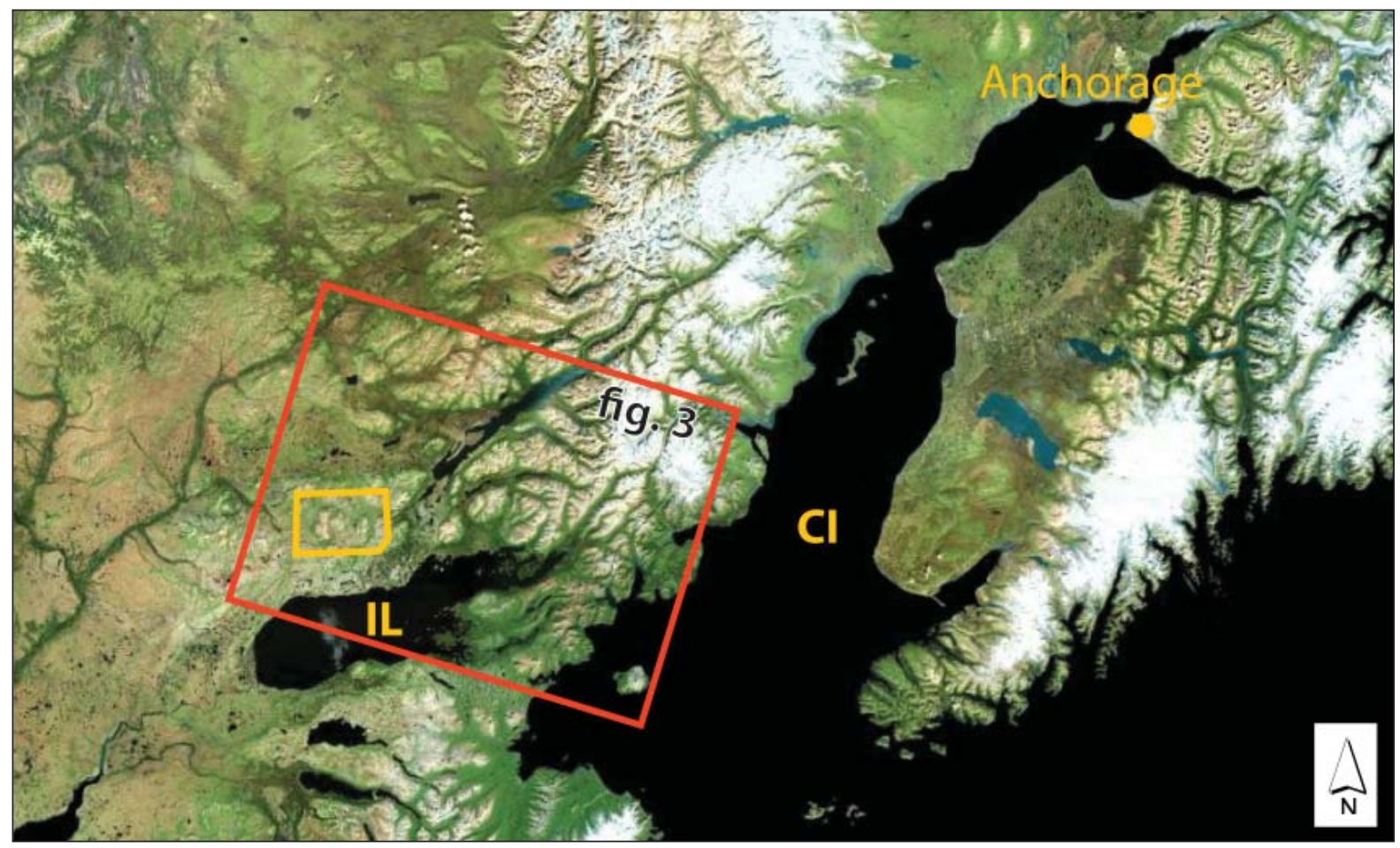

Figure 1. Map area (small rectangle), showing relations to Iliamna Lake (IL), Cook Inlet (CI), and modern glaciers of Alaska and the Kenai Peninsula (center and right side of image, respectively). Large rectangle shows figure 3 area.

\section{REGIONAL SETTING}

The map area is situated near the southwestern end of Lake Clark, which fills a remarkably straight-sided and elongate trough (fig. 3) carved by glaciers along a zone of crustal fracture known as the Lake Clark fault (Detterman and others, 1976). This trough served as a major conduit for glaciers that originated in icefields around its headwaters. Large glaciers from those icefields repeatedly flowed south-southwest down Lake Clark trough, bifurcating near the southwestern end of that depression into separate bodies that flowed southwestward into the Iliamna Lake area via the lowlands now occupied by the Newhalen River and west-southwest toward Bristol Bay through the broad trough now occupied by the Chulitna River drainage.

Iliamna Lake, which is situated immediately south of the map area, occupies a large basin that is enclosed at its western end by a huge end-moraine complex (Detterman and Reed, 1973). The origin of the successive glaciers that built that enormous complex is not immediately obvious. Those glaciers must have been significantly larger than any Pleistocene glaciers known on the Alaska Peninsula and, as discussed later in this report, they may have been derived from a large glacier complex that formed on the continental shelf farther to the southeast during times of lowered glacial-eustatic sea levels (Mann and Peteet, 1994; Stilwell and Kaufman (1996).
The map area lies in the zone of sporadic permafrost as mapped by Ferrians (1965) and Brown and others (1997), although it is very close to the southern limit of that zone. Solifluction lobes on mountainsides and apparent thaw ponds in some poorly drained lowlands suggest that permafrost may be present locally or may recently have thawed as result of warming climate. Auger tests in June 2007 encountered frozen ground at very shallow depths $(30 \mathrm{~cm}$ ) in some lowlands, but relict seasonal frost could not be distinguished from permafrost that early in the summer without mechanical excavation.

\section{LOCAL GEOGRAPHIC SETTING AND NOMENCLATURE}

Terrain in the map area has moderate relief, consisting of isolated low mountain masses (termed "mountain blocks" in this report) that stand $450-700 \mathrm{~m}$ above lake-filled lowlands (cover; figs. 2 and 4). The area is drained by three principal stream systems. The North and South Forks of Koktuli River drain its western half; Upper Talarik Creek and an eastern headward branch of that creek drain the eastern half. Many of the numerous ponds in the map area occupy kettle depressions in glacial deposits. The few larger water bodies are also glacial in origin. For example, end moraines enclose Frying Pan Lake in the center of the map area and Cone Lake near its northwestern corner; and Wiggly Lake is 


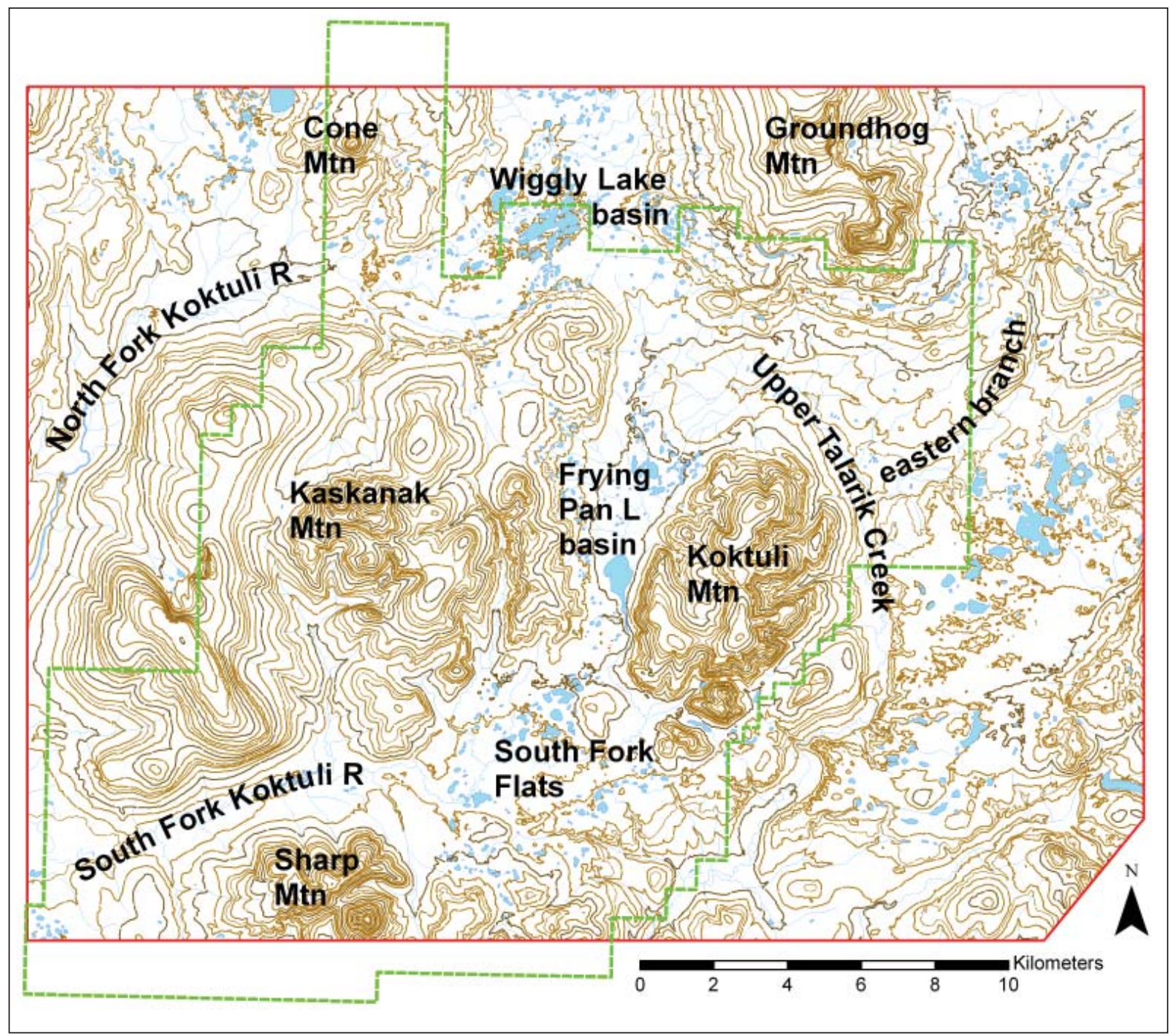

Figure 2. Map area (outlined in red), showing topographic features, drainages, and Pebble claim block (outlined in green). See figure 1 for location.

situated in ice-stagnation deposits at the head of Koktuli River's North Fork.

Individual mountain blocks rise to altitudes of 700-900 $\mathrm{m}$ and control the patterns of both present-day drainage and late Pleistocene glacier flow. Those blocks are informally named here as extensions of the names assigned to their most prominent peaks or benchmarks. The highlands east and west of Frying Pan Lake are termed the Koktuli and Kaskanak Mountain blocks, respectively. The Cone Mountain block stands near the northwestern corner of the map area and the Sharp Mountain block near the southwestern corner. The large and complex upland in the northeastern sector of the map area is termed the Groundhog Mountain block.

Glacier flow into the map area repeatedly dammed the three major drainages, creating lake-filled basins that are occupied today by poorly drained lowlands with numerous ponds and silty to clayey subsoils.
Four principal basins are recognized in the map area: (1) South Fork Flats at the head of South Fork of Koktuli River, (2) Wiggly Lake basin at the head of the Koktuli River's North Fork, (3) Frying Pan Lake basin, which includes the lake of that name and the area immediately north of it, and (4) unnamed lowlands at the head of Upper Talarik Creek.

\section{THE GLACIAL RECORD GLACIER DISTRIBUTION AND FLOW PATTERNS}

The surficial geology of the map area is dominated by the direct and indirect effects of a series of late Pleistocene glaciations. Glaciers flowed into this area from four directions (fig. 3), depositing prominent end moraines (fig. 5). Overflow from the Chulitna tongue of the Lake Clark glacier entered northern parts of the 


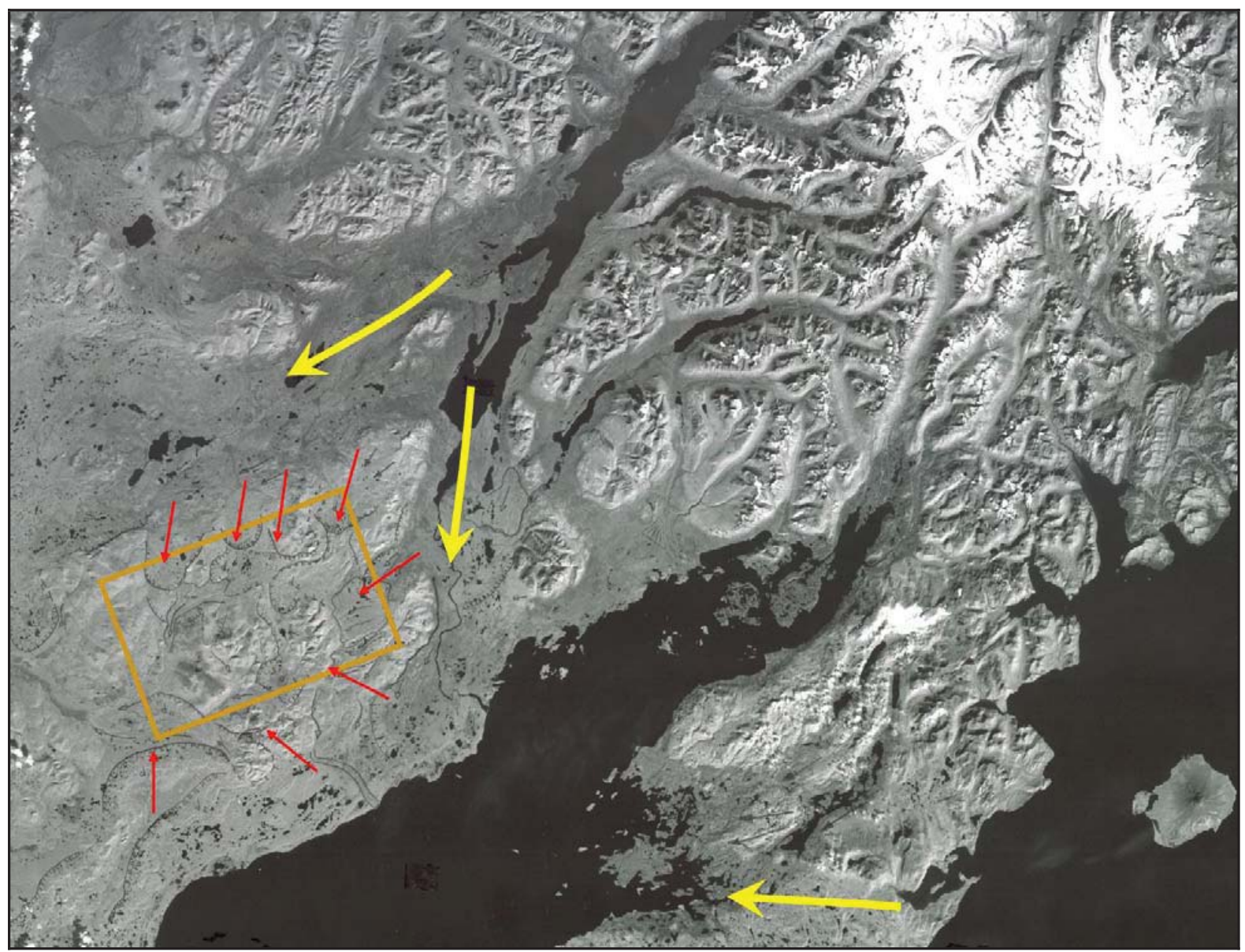

Figure 3. Satellite image of Lake Clark-Iliamna Lake area. Large yellow arrows show principal routes followed by glaciers issuing from Lake Clark trough, and outlet glacier flowing westward from Cook Inlet into Iliamna Lake basin. Small red arrows show routes of glacier flow into map area (orange rectangle).

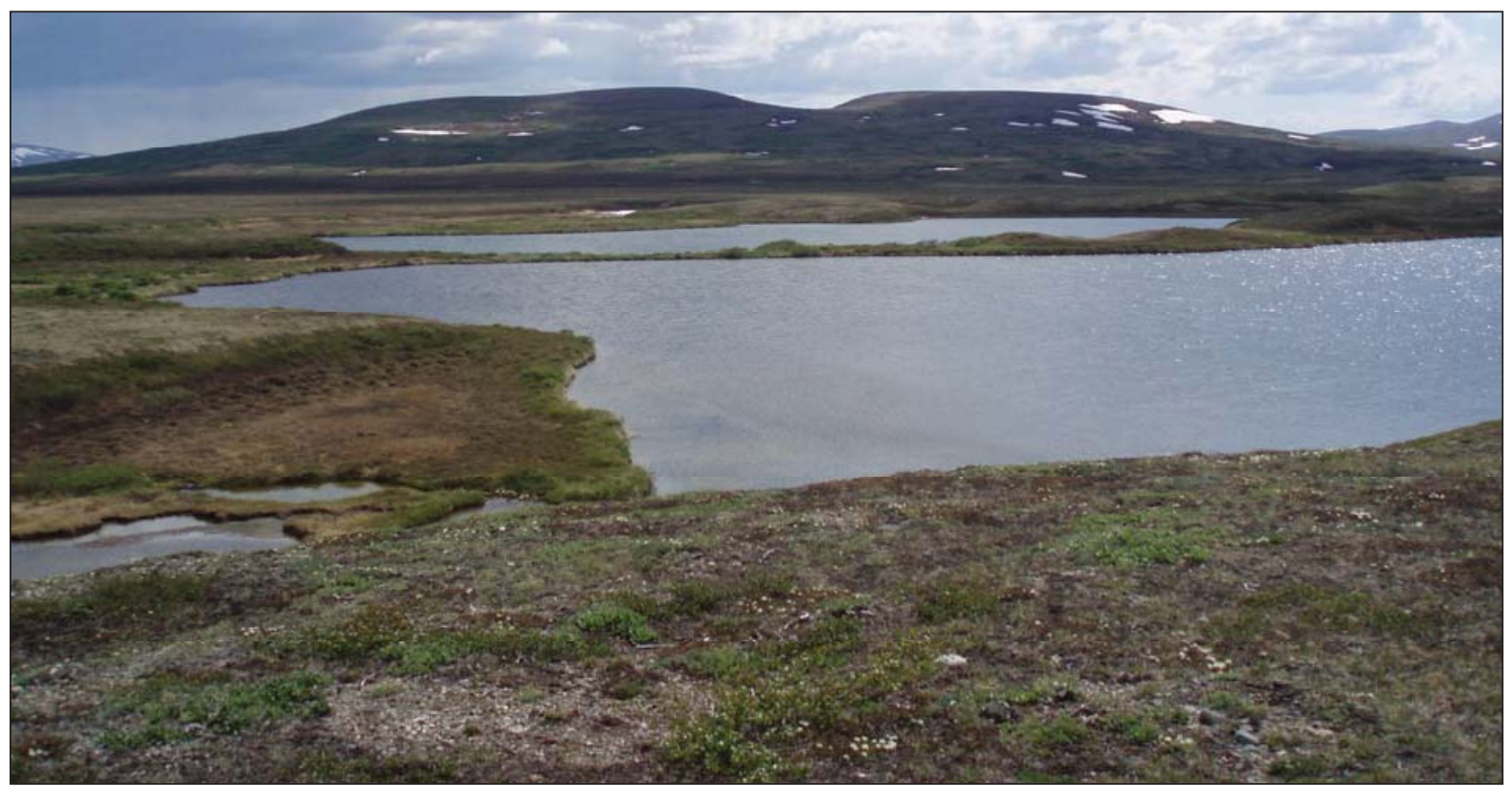

Figure 4. Terrain features typical of map area. View eastward showing Groundhog Mountain block (background) and lake-filled Wiggly Lake basin (foreground). 
map area west of the Cone Mountain block, east of the Groundhog Mountain block, and between those two upland areas. A broad trough carved into bedrock in the east-central part of the map area reflects the influx of southwest-flowing glacier ice from the Newhalen tongue of the Lake Clark glacier. The massive Iliamna Lake glacial lobe also encroached on the extreme southwestern corner of the map area and extended into south-central and southeastern areas of the map as well.

Small glaciers issued from a cirque on the Groundhog Mountain block and from a pair of cirques on the western flank of the Kaskanak Mountain block. A small ice cap above the Kaskanak cirques must have existed at one time and been the source for morainal deposits and trains of erratic boulders in the south-trending valley that bisects the Kaskanak Mountain block.

\section{GLACIAL SEQUENCE, CORRELATIONS, AND INFERRED CHRONOLOGY}

Surficial deposits relating to four glacial intervals are recognized in the map area. The oldest deposits (designated $\mathbf{d}_{\mathbf{0}}$ on fig. 5 and sheet 1 ) reflect one or more glaciations that preceded the last glacial maximum, which is locally termed the Brooks Lake glaciation (Detterman and Reed, 1973). These deposits generally are restricted to isolated erratic boulders and cobbles and to thin and discontinuous patches of drift that overlie bedrock at altitudes above the limits of younger glacial advances. However, a well-defined moraine is associated with those bedrock features in the southwestern corner of the map area, and a probable end moraine is

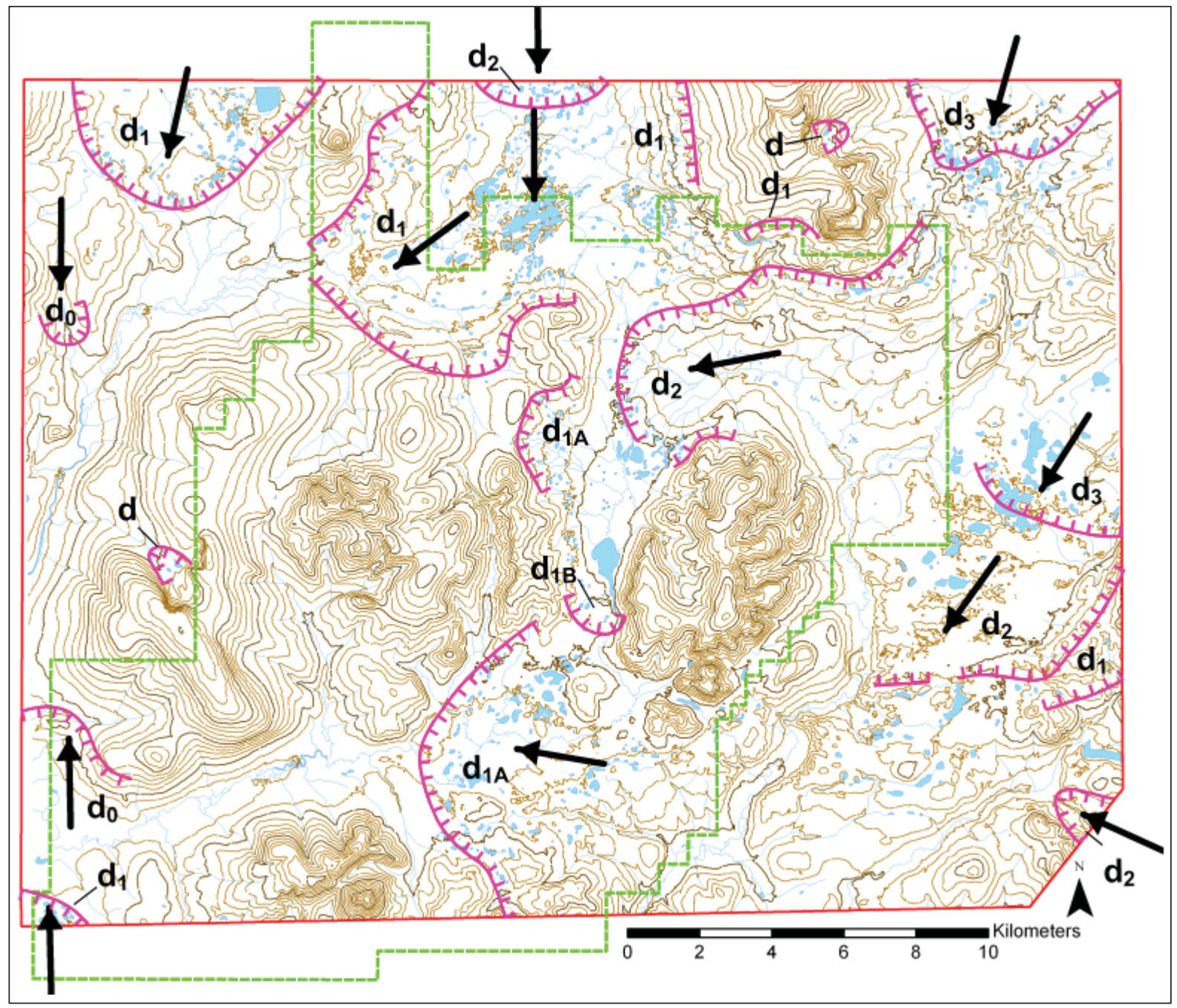

Figure 5. Principal end moraines deposited by glaciers of middle to late Pleistocene age ( $d_{o}$, oldest; $d_{3}$, youngest). Arrows show inferred glacier-flow directions. Discontinuous moraine fragments not shown. 
present near the mouth of an unnamed northern tributary to the North Fork of Koktuli River near the map area's northwestern corner. These moraines may be assignable to the Mak Hill glaciation, which preceded the Brooks Lake advances (Muller, 1953; Detterman and Reed, 1973). Mak Hill deposits are undated, but are known to be older than 39,400 radiocarbon years $\mathrm{BP}\left({ }^{14} \mathrm{C}\right.$ yr BP $)$ (Mann and Peteet, 1994). Drift and glaciated bedrock surfaces of pre-Brooks Lake age were modified by severe periglacial activity during the subsequent Brooks Lake glaciation (figs. 6 and 7).

Three younger glacial advances formed distinctive sets of arcuate end moraines and associated glacial deposits (map units $\mathbf{d}_{1}, \mathbf{d}_{2}$, and $\mathbf{d}_{3}$, from oldest to youngest) through most of the lowlands in the map area. Based on prior mapping by Detterman and Reed (1973), these advances, from oldest to youngest, are assigned to the Kvichak, Iliamna, and Newhalen stades of the Brooks Lake glaciation, which they correlate with the Late Wisconsin substage of the standard North American glacial chronology. Although not directly dated in the map area, this sequence of glacial advances probably falls within the age range of 26,000 to $10,000{ }^{14} \mathrm{C}$ yr $\mathrm{BP}$ indicated by radiocarbon dating elsewhere on the Alaska Peninsula (Stilwell and Kaufman, 1996). Radiocarbon dates from Kodiak Island and the Kenai Peninsula suggest a comparable age range of about 25,000 to $10,000{ }^{14} \mathrm{C}$ yr $\mathrm{BP}$ for the last glacial succession in that region (Reger and Pinney, 1997). Widespread eolian deposits derived from glacial outwash around the head of Bristol Bay date 25,000 to $12,500{ }^{14} \mathrm{C}$ yr BP (Lea, 1990), implying that glacial maxima within that general age range occurred across a broad region.

During the Kvichak and Iliamna stades, very large glacier lobes filled the Iliamna Lake basin, and expanded northward into southern parts of the map area. Concurrently, the two arms of the Lake Clark glacier flowed southward to coalesce with the Iliamna Lake ice and westward to fill the upper valley of the Chulitna River. Ice from these sources flowed into northern, central, and eastern parts of the map area. These advances are undated locally, but outwash assigned to the Kvichak stade

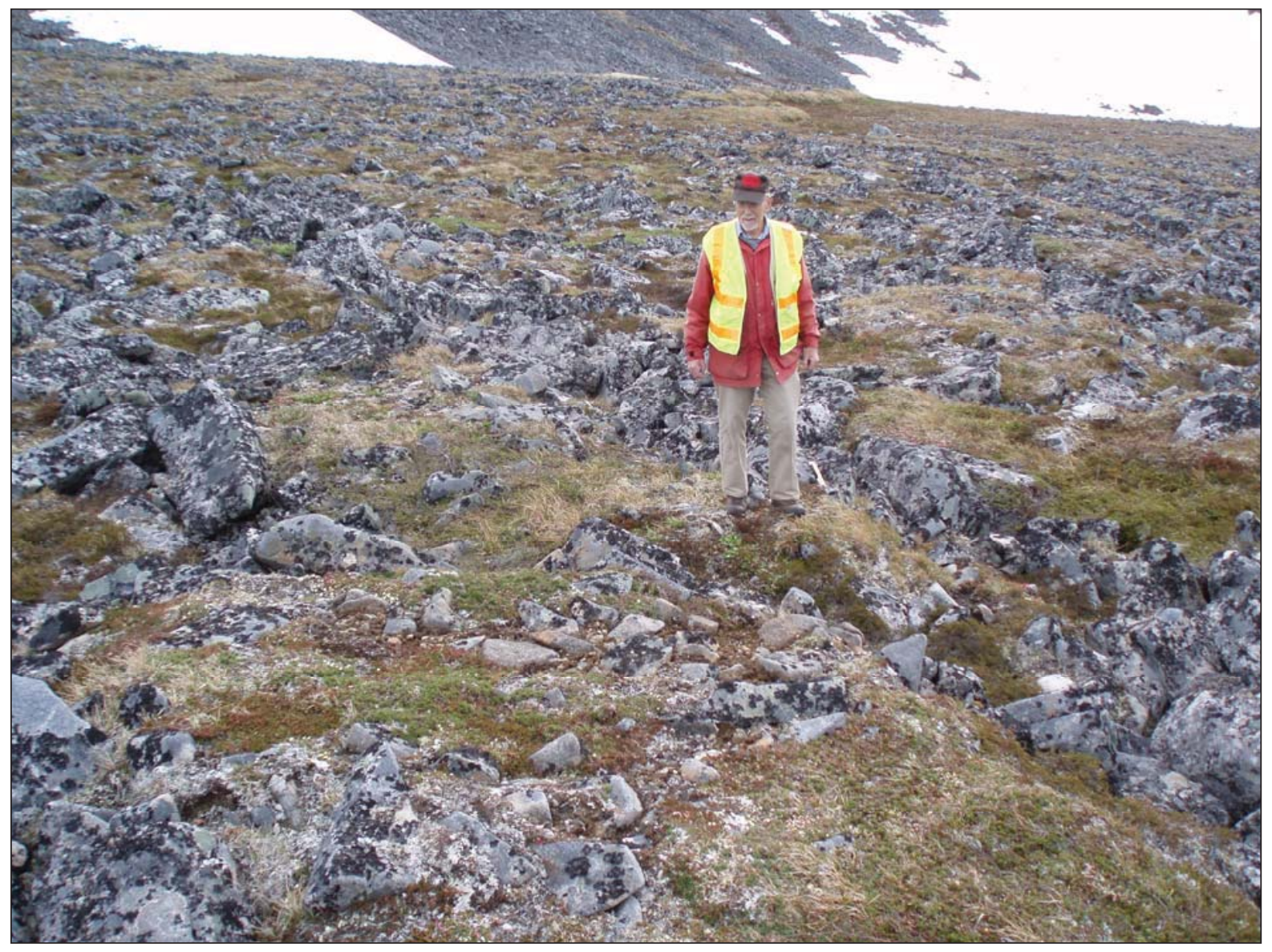

Figure 6. Glacial deposits of pre-Brooks Lake age on Kaskanak Mountain block. Drift was modified into stone net by periglacial frost action during Brooks Lake glaciation. The net became stable during Holocene time, and currently is inactive. 

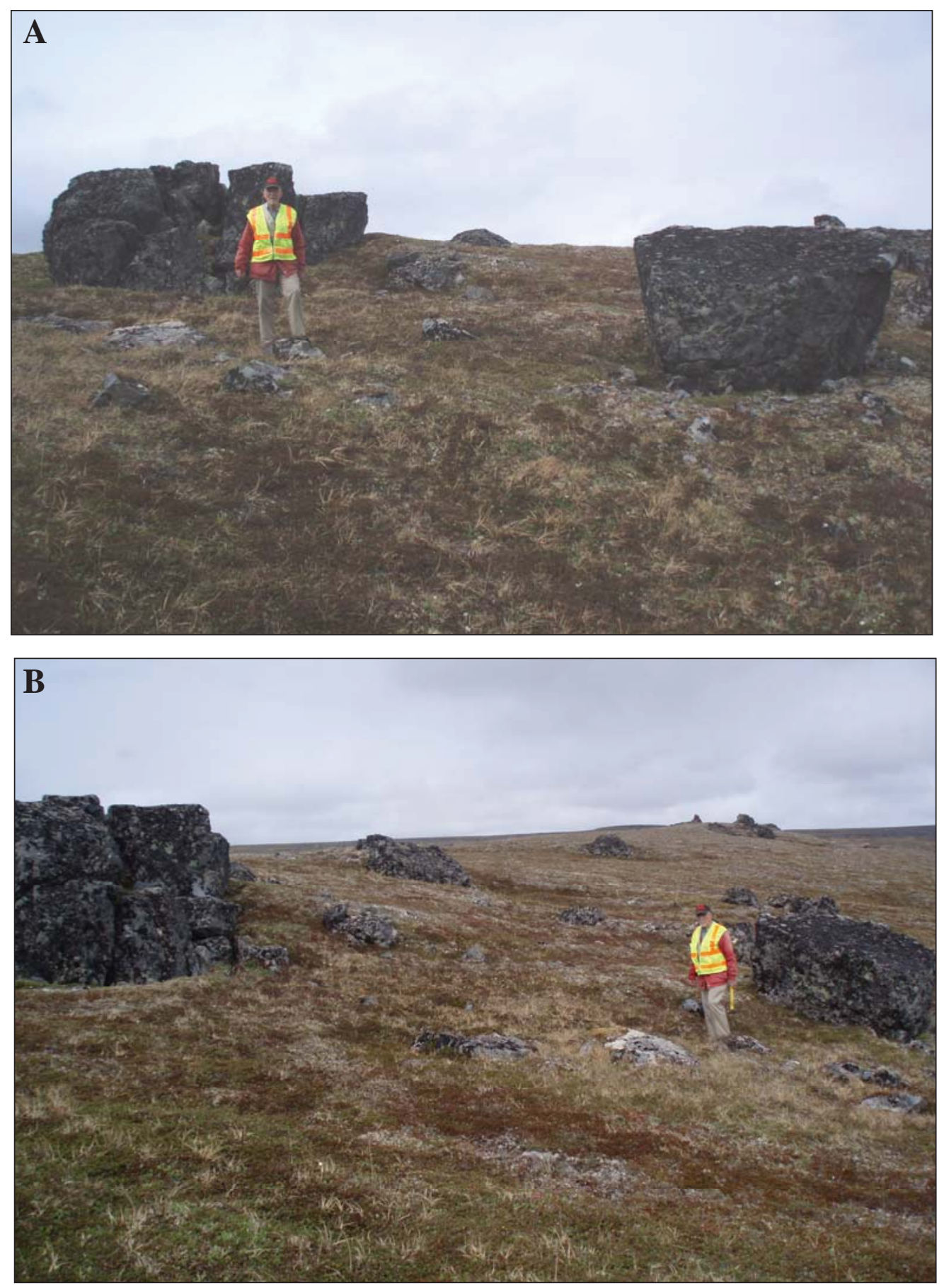

Figures 7A and 7B. Two views of gabbro bedrock outcrop (left side of photos) on Kaskanak Mountain block. Erratic clasts on its surface demonstrate that outcrop was overridden by glacier during pre-Brooks Lake time. Subsequent periglacial frost activity during Brooks Lake glaciation wedged blocks loose from outcrop and transported them downslope (toward right side of photos). Outcrop face currently is weathered and lichen-covered, and blocks have become stable. 
buried organic deposits dated about 26,500 to 26,000 ${ }^{14} \mathrm{C}$ yr BP in two nearby drainages (Mann and Peteet, 1994; Stilwell and Kaufman, 1996). The termination of two comparable advances in Cook Inlet is dated at about 16,500 to $16,000{ }^{14} \mathrm{C}$ yr BP (Reger and Pinney, 1997; Reger and others, 2007). Ice retreated from most of Cook Inlet at that time, and no longer could have overflowed into the basin of Iliamna Lake.

During the Newhalen stade, the youngest advance recognized in the map area, ice flowed from the Lake Clark region into extreme northeastern and east-central parts of the map area. According to Stilwell and Kaufman (1996), moraines assignable to the Newhalen stade have narrower crests and markedly steeper flanking slopes than moraines of the Kvichak and Iliamna stades; they suggest that a considerable time span therefore may have separated the younger event from the two older advances of Brooks Lake age. Although no radiocarbon dates are available for the Newhalen stade in the map area, the possible correlation of that stade with the widespread Elmendorf advance in upper Cook Inlet (Schmoll and others, 1972; Reger and others, 1995) implies that an age of about 14,000 to $13,500{ }^{14} \mathrm{C}$ yr BP is likely. A terrace around Iliamna Lake that is correlated with the Newhalen stade was deposited sometime before 12,600 ${ }^{14} \mathrm{C}$ yr BP, (Kaufman and Stilwell, 1997), lending some support to that age inference. The Lethe tephra, a widespread volcanic ash that originated in the Katmai area, is present on glacial deposits that formed following the Newhalen stade (Pinney and Begét, 1991). Although tephras closely resembling the type Lethe bed are now known to have formed during repeated eruptions (Riehle and others, 2008), a single bed dated at about $13,000{ }^{14} \mathrm{C}$ yr BP is most widely present on the Alaska Peninsula north of the Katmai area. This tephra therefore may provide a further minimum limiting age on deposits of the Newhalen stade.

Glaciers in upper Cook Inlet had retreated into mountain valleys by $10,000{ }^{14} \mathrm{C}$ yr BP (Reger and Pinney, 1997), and the warmest postglacial temperatures in Alaska were recorded during that time and shortly thereafter (Kaufman and others, 2004). Final meltout of stagnating glaciers in the map area must have taken place by that time.

\section{GLACIAL MORPHOLOGY}

Glacial deposits in the map area form generally arcuate end moraines that enclose areas of irregular hummocky drift with abundant dry to water-filled kettle depressions (figs. 8A and 8B). Well-defined linear moraine crests (linear stippled symbol on sheet 1 ) are common (figs. 8C and 8D), but are not universally present. Outwash gravel (map units $\mathbf{o}_{1}, \mathbf{o}_{2}$, and $\mathbf{o}_{3}$, from oldest to youngest) forms broad aprons and linear belts (valley trains) that extend downslope or downvalley from terminal moraines near the head of both North and South Forks of Koktuli River (figs. 9A and 9B). Multiple terrace levels ( $\mathbf{t g}_{1}$ and $\mathbf{t g}_{2}$ ) of probable outwash occur farther east in the map area. Outwash segments close to moraine fronts commonly are kettled, indicating that meltwater streams developed headward above stagnant and downwasting glacier ice. These kettled segments are designated by compound units (o/d, with appropriate subscripts on sheet 1 ). Ice-contact meltwater deposits that formed as glaciers downwasted (unit i-c) are represented by irregular terrain with conical to subdued mounds, short ridges, abundant dry to waterfilled kettle depressions, and meltwater channels (fig. 10) that contain little or no modern drainage. Meltwater deposits in the South Fork Flats and east of the Upper Talarik drainage contain numerous small kettle depressions 20 to $30 \mathrm{~m}$ in diameter and generally 3.0 to $3.5 \mathrm{~m}$ deep. These features may have been formed by meltout of icebergs carried from disintegrating glacier termini, perhaps by periodic floods that burst out from beneath those glaciers.

\section{GLACIER-DAMMED LAKES}

Influx of glaciers into the map area disrupted preexisting drainage patterns. Glaciers impounded lakes along and beyond their margins as they advanced to their maximum positions, where they built terminal moraines that enclosed younger sets of lakes during subsequent glacial downwastage and retreat. Most of these former lakes are now dry, but they are represented by smoothsurfaced, poorly drained expanses of silt-rich sediment with negligible to moderate slope that terminate abruptly upslope at consistent altitudinal limits (fig. 11A). Distinctive linear beach ridges fronting on wave-planed platforms (unit b) commonly are present at these lake limits (fig. 11B). Delta and fan-delta deposits (units dt and fd, respectively) are distinctive landform features at places where meltwater streams entered the lakes (fig. 11C). Surficial deposits are rare where the lakes lapped up against areas of more rugged relief, but wave erosion has smoothed bedrock outcrops and modified glacial deposits in those areas (fig. 11D). The modified terrain commonly terminates upslope at wave-eroded notches, also at characteristic altitudinal limits. The former lake limits define generally horizontal planes through the central part of the map area, but they appear to rise by $30 \mathrm{~m}$ or more toward its northeastern corner. This tilting of the lake planes is a common response to isostatic rebound, which is greatest where former glaciers were thickest and most extensive.

Three major lake stages are recognized in the map area. The oldest (unit $\mathbf{g l}_{\mathbf{1}}$ ) rises to altitudes of about $357 \mathrm{~m}$

\footnotetext{
${ }^{3}$ Altitudes of lake limits are given parenthetically in feet to facilitate locating them on sheet 1 , which is drafted on a topographic base
} with 50-ft contours. 

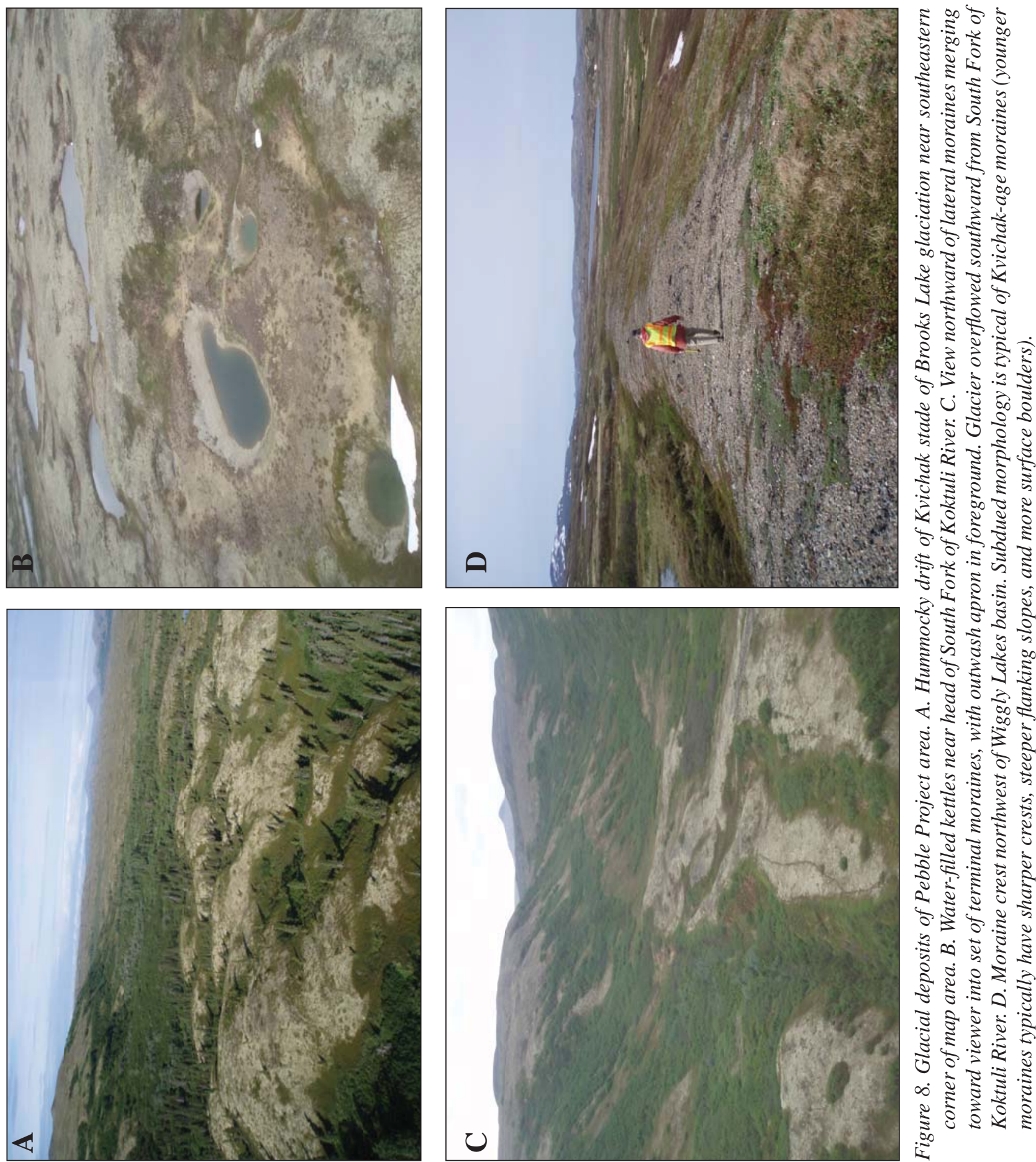

I

ปั

ह

हิ

일

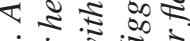

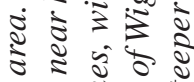

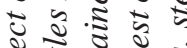

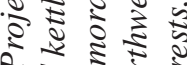

का

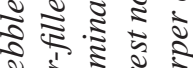

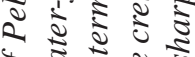

$\frac{1}{3} \approx$ के

$\cong$

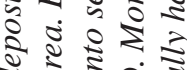

8.

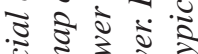

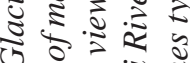

$0 . \overline{5}$

$\infty$ है

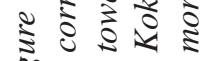




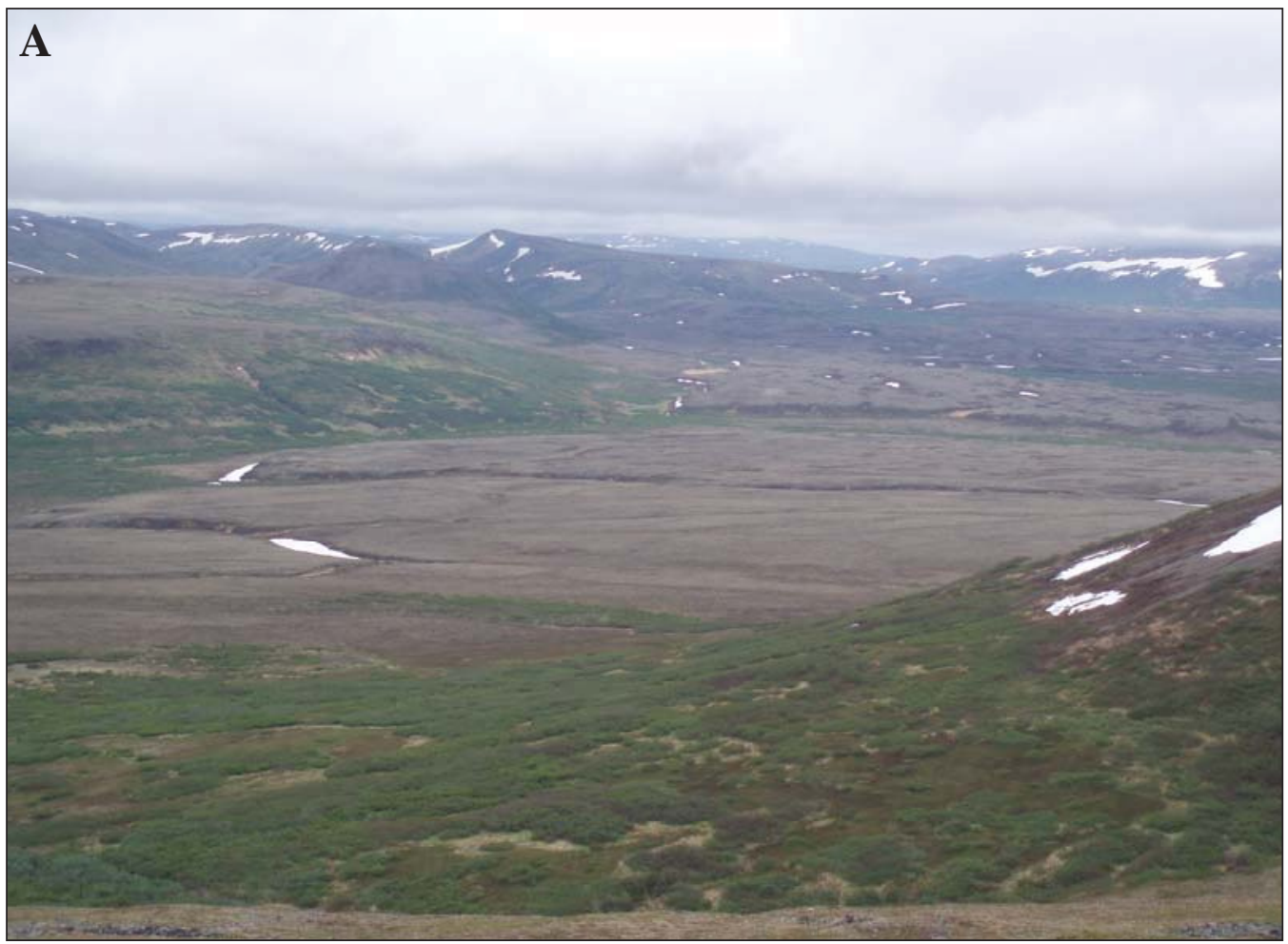

B

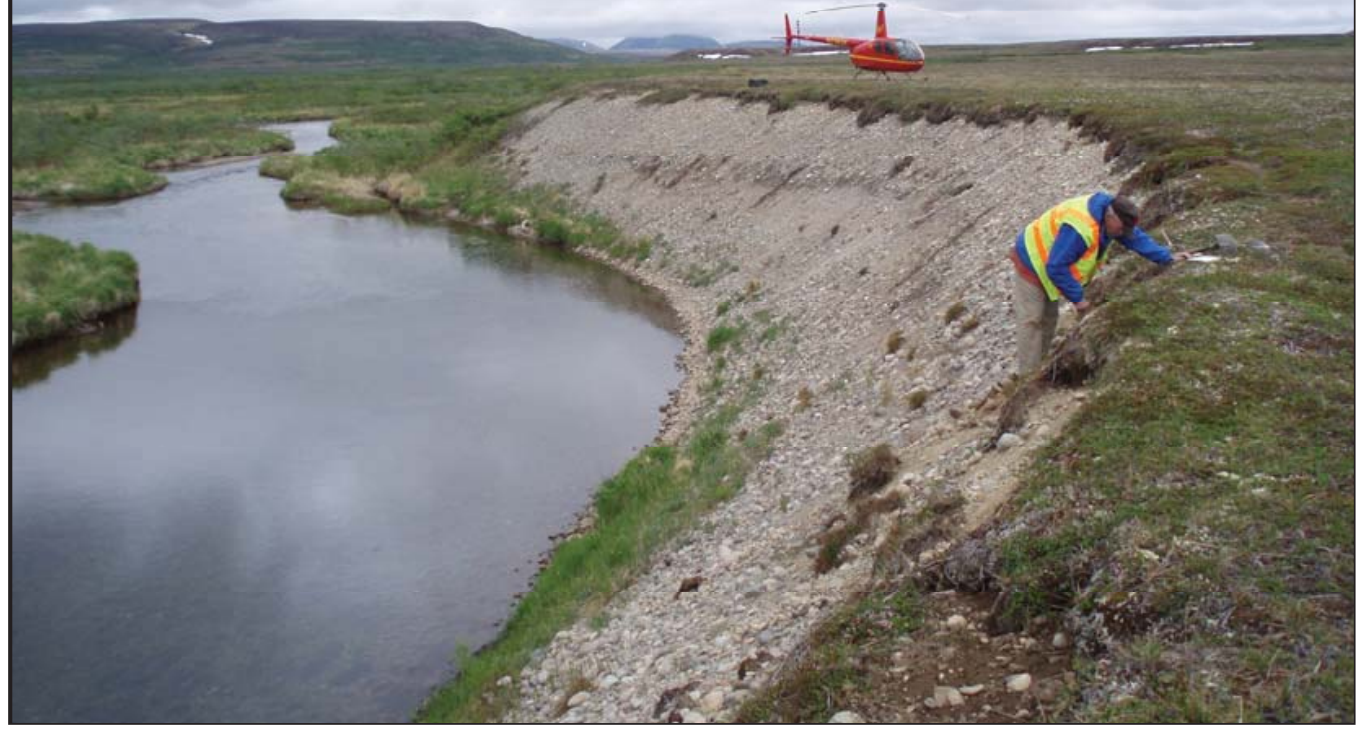

Figure 9. Outwash of Kvichak stade age on South Fork of Koktuli River. A. View to east up outwash plain. Irregular-surfaced drift sheet in background contacts head of outwash. Koktuli Mountain block on near skyline. B. Outwash terrace along South Fork. Present-day river channel is underfit within large outwash-filled trough. 


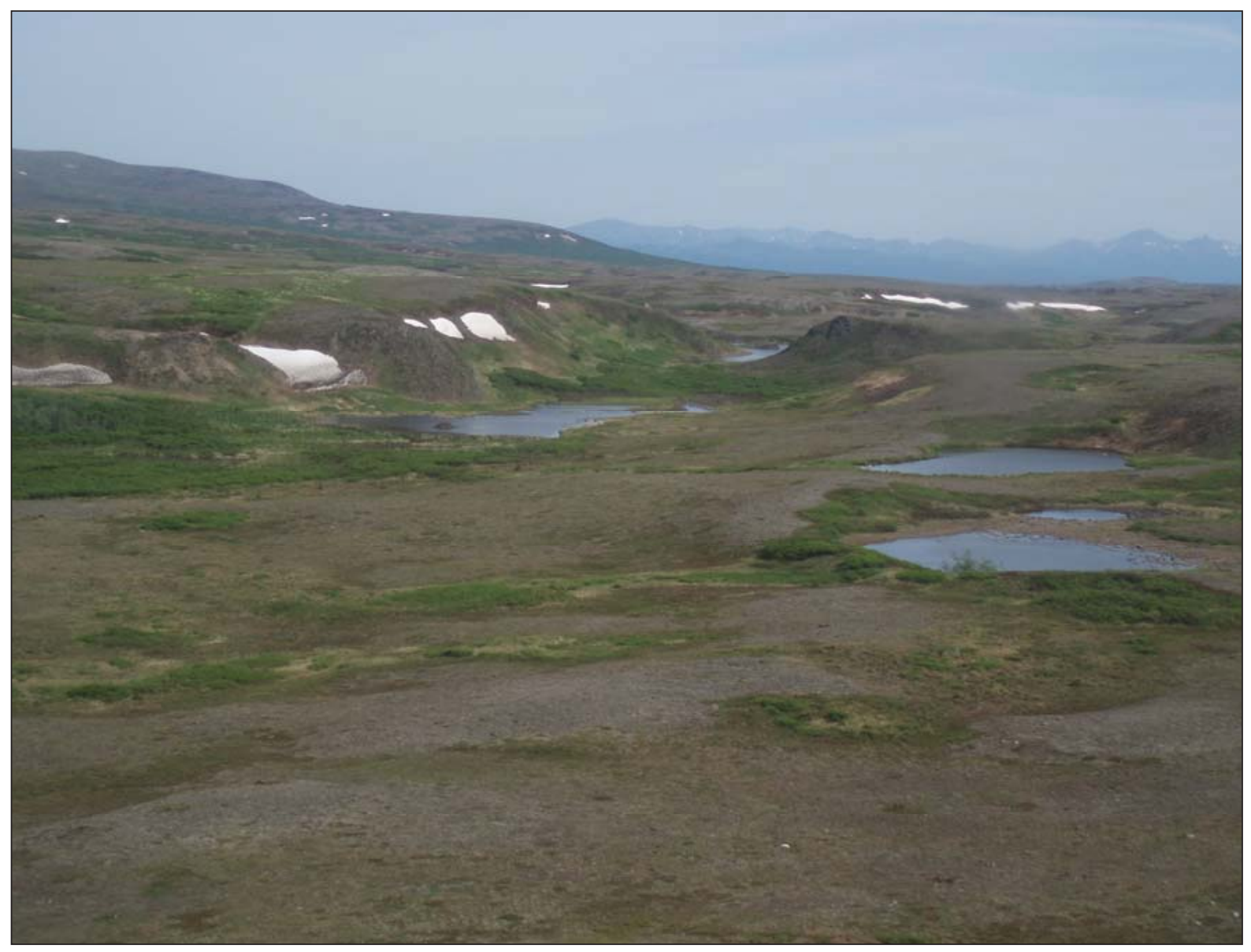

Figure 10. Abandoned ice-marginal meltwater channel on south flank of Groundhog Mountain block. View northeast, with Groundhog Mountain block forming near skyline at upper left. Hummocky glacial drift in foreground.

$(1,170 \mathrm{ft})^{3}$ in the Wiggly Lake basin and may be present locally around the basin north of Frying Pan Lake. This former lake was enclosed within deposits of Kvichakstade glaciers (unit $\mathbf{d}_{1}$ ), and therefore, dates from the deglaciation phase of that event. The next younger lake deposits (unit $\mathbf{g l}_{2}$ ) formed during and after the Iliamnastade advance. These deposits rise to maximum altitudes of about $323 \mathrm{~m}(1,060 \mathrm{ft})$ in the basin north of Frying Pan Lake and across the broad valley floor at the head of Upper Talarik Creek. They may rise higher farther to the northeast near the headwaters of the Talarik's eastern branch. Deposition of the youngest lake sediments (unit $\mathbf{g l}_{3}$ ), which rise from 245 to $275 \mathrm{~m}$ (800-900 ft) altitude northeastward along the drainage of Upper Talarik Creek, followed the Iliamna stade later during its deglaciation and continued during and after the Newhalen stade. The lake surface progressively lowered with time as Upper Talarik Creek eroded downward through the moraine complex along the northern margin of Iliamna Lake that had confined that drainage. Based on presence of the Lethe tephra, Stilwell (1995) and Kaufman and Stilwell (1997) determined that the surface of Iliamna
Lake (which serves as base level for the Upper Talarik drainage) lowered to within $30 \mathrm{~m}$ of its present elevation by $12,600{ }^{14} \mathrm{C}$ yr BP. The last large glacial-age lakes in the map area must have been drained by that time.

\section{DISCUSSION AND SYNTHESIS}

The map area and its drainage system have been strongly impacted by the effects of repeated late Pleistocene glaciations. Glaciers that flowed into this area originated from two principal sources. A relatively narrow glacier, confined by the Lake Clark structural trough, flowed southwestward down that trough then split into separate glacier tongues that followed the present-day Chulitna and Newhalen drainages. Ice overflowed from those drainages into the map area from the north and northeast, respectively. Multiple advances of a separate and much larger glacier repeatedly filled the huge basin now occupied by Iliamna Lake. That glacier built the impressive moraine complex that encloses the western part of the basin (Detterman and Reed, 1973), and also expanded northward into southern parts of the map area. 

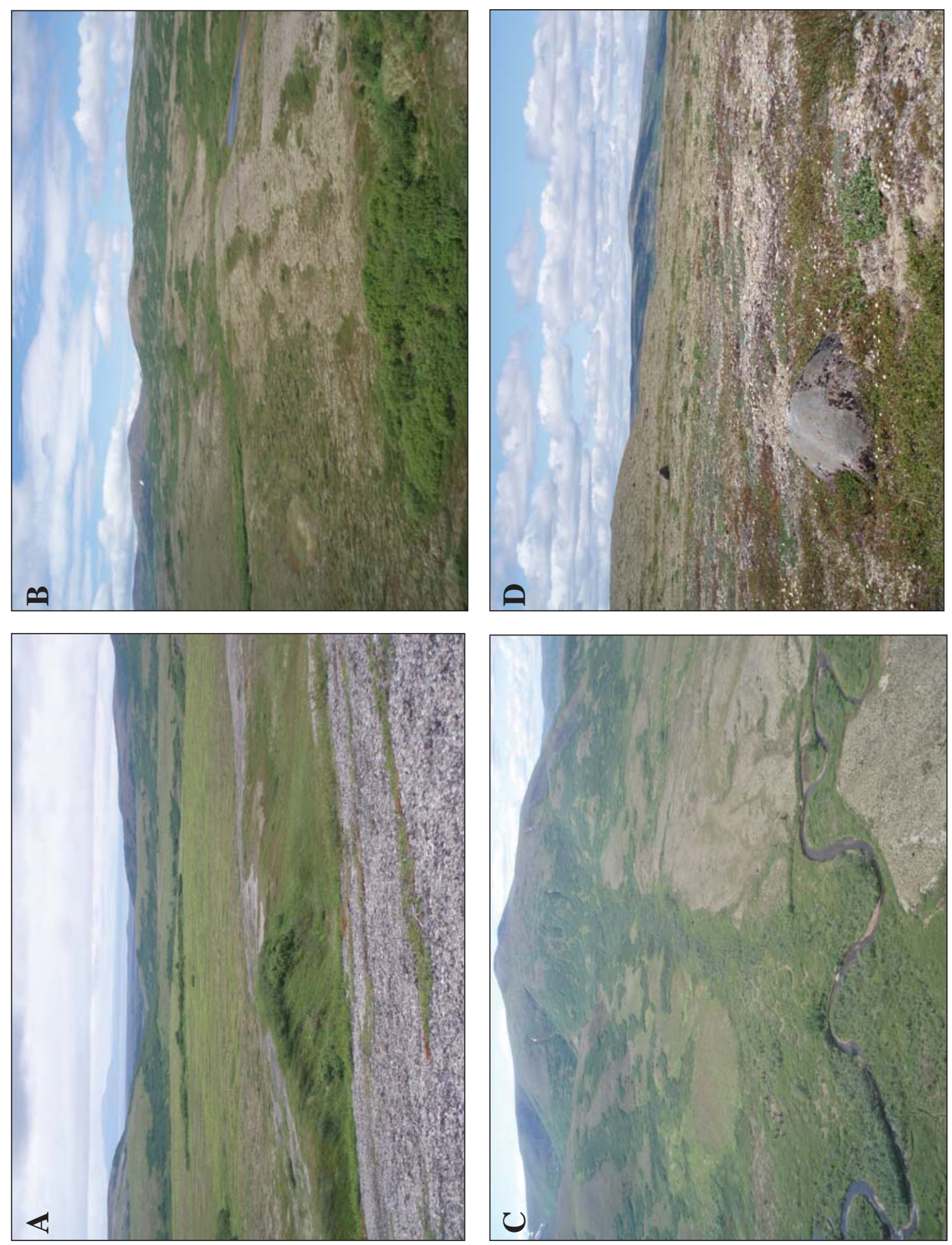

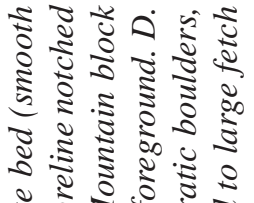

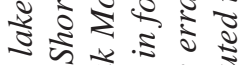

๙

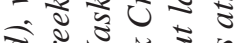

ఫิ

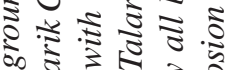

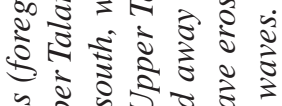

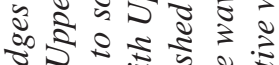

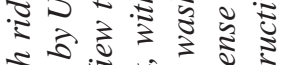

पृ

๓

म

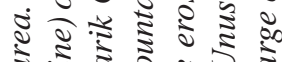

ป.

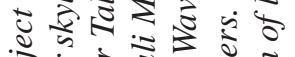

ล $\div 25 \frac{2}{2}$

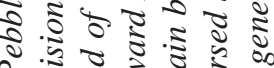

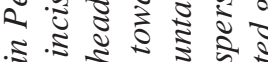

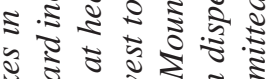

ป วิ

ఫี

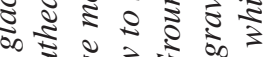

ปิ

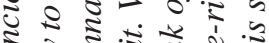

ป

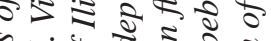

थ ชं

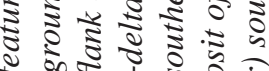

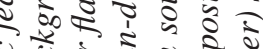

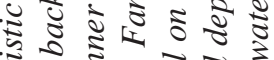

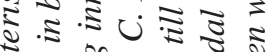

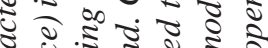

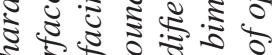

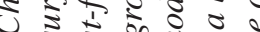

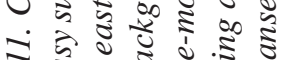

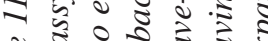

ईँ. 
The origin of the successive glaciers that built the huge moraine complex around the west end of Iliamna Lake is not immediately obvious. Those glaciers are greater in size than any Pleistocene glaciers known on the Alaska Peninsula (as illustrated in Detterman, 1986), and the west-southwest to east-northeast (WSW-ENE) orientation of Iliamna Lake differs markedly from the north-northeast to south-southwest (NNE-SSW) orientation of Lake Clark and other fault-controlled troughs elsewhere on the northern Alaska Peninsula. Only limited source areas of low to moderate relief enclose the head of Iliamna Lake, so their contribution to the huge glaciers that filled its basin and constructed the massive moraines that enclose it must have been relatively minor. Ice from a large glacier complex on the continental shelf southeast of the Alaska Peninsula (Mann and Peteet, 1994) probably overflowed westward to build the moraine system that dams the present-day lake, as advocated by Stilwell and Kaufman (1996). A likely route for that overflow was west-northwestward across a broad, low-lying, glacier-abraded trough that crosses the Aleutian Range from southwestern Cook Inlet at altitudes close to sea level and intersects the southeastern shore of Iliamna Lake (fig. 3).

The surficial geology of the map area is dominated by arcuate end moraines, meltwater deposits with abundant kettle depressions, broad outwash aprons and elongate valley trains, and striking meltwater channels. At various times the glaciers that entered the map area blocked each of its three major drainages: Upper Talarik Creek and the North and South Forks of Koktuli River. The resulting ice-dammed lakes filled lowlands in headward parts of each drainage. The floors of those former water bodies are marked by broad expanses of unusually smooth, poorly drained, and gently sloping terrain, and by streams that meander between silty banks and commonly lack channel-bar deposits of sand or gravel. Former lake beds terminate abruptly upslope at consistent altitudes and are commonly bordered by beach and deltaic deposits. Wave-eroded notches and boulder-littered gravel surfaces are present in areas where glacial deposits were exposed to strong wave activity. Ice wastage following each glacial advance generally was by stagnation rather than retreat of glacial termini, resulting in extensive areas of ice-contact meltwater deposits and in numerous meltwater channels that today are abandoned or contain only very small streams. A large lake in the Upper Talarik Creek area may have persisted into latest Pleistocene time.

At least four episodes of glaciation are recognized in the map area. During the oldest of these advances, which preceded the Brooks Lake glaciation of late Wisconsin age, glaciers expanding northward from Iliamna Lake formed a conspicuous moraine that dammed the South Fork of Koktuli River near the southwestern corner of the map area (fig. 12). Glacier ice also approached the North Fork of Koktuli River, and that glacier or its outwash may have dammed that drainage as well. A probably contemporaneous south-flowing glacier penetrated the valley complex that divides the Kaskanak Mountain block into eastern and western halves, and a small ice cap may have formed on the western part of the Kaskanak block at that time. Through central and eastern parts of the map area, evidence for pre-Brooks Lake glaciation is preserved primarily on ice-abraded uplands above the limits of extensive younger glacial advances. Erratic boulders and dispersed patches of drift are present along the western flank of Groundhog Mountain to nearly 600 m (2,000 ft) altitude. Similar erratics and drift patches are present to about $450 \mathrm{~m}(1,500 \mathrm{ft})$ in north-central parts of the map area and to perhaps $400 \mathrm{~m}(1,350 \mathrm{ft})$ in south-central parts. These limits appear to define a coalescent glacier complex, with surface gradient inclined toward the southwest, that covered all but upper parts of the major mountain blocks.

The younger three glacial advances correspond to the three oldest stades of the Brooks Lake glaciation, which Detterman and Reed (1973) equate with the late Wisconsin glacial substage of the standard North American glacial succession. This interval is dated at about 26,000 to $10,000{ }^{14} \mathrm{C}$ yr BP elsewhere on the Alaska Peninsula (Stilwell and Kaufman, 1996) and at about 25,000 to $10,000{ }^{14} \mathrm{C}$ yr BP in the Cook Inlet region (Reger and Pinney, 1997).

During each of the two oldest Brooks Lake stades, termed Kvichak and Iliamna by Detterman and Reed (1973), ice filled the Lake Clark trough and coalesced with the huge glacial lobe that filled the basin now occupied by Iliamna Lake. Glaciers of the Kvichak stade, the initial and most extensive advance, entered western parts of the map area from both north and south, but did not coalesce there (fig. 13). Farther east, large glaciers penetrated the map area from the north, south, and east; these glaciers coalesced through most lowlands. Ice covered all but the highest mountain blocks through eastern parts of the map area, and extended for short distances farther west into headwaters of the North and South Forks of Koktuli River. Cirques on the Groundhog Mountain and Kaskanak Mountain blocks probably were active at this time, generating small glaciers.

During the succeeding Iliamna stade, glaciers penetrated the map area primarily from the northeast. Smaller glaciers entered the north-central and southeastern parts of the map area at that time, but they did not extend far into it. The glaciers that entered the northeastern part of the map area coalesced into a large mass that then bifurcated into a western lobe that filled the headwaters of Upper Talarik Creek and a southern lobe that extended down that creek (fig. 14). The western lobe probably terminated in a lake that had been dammed behind the 


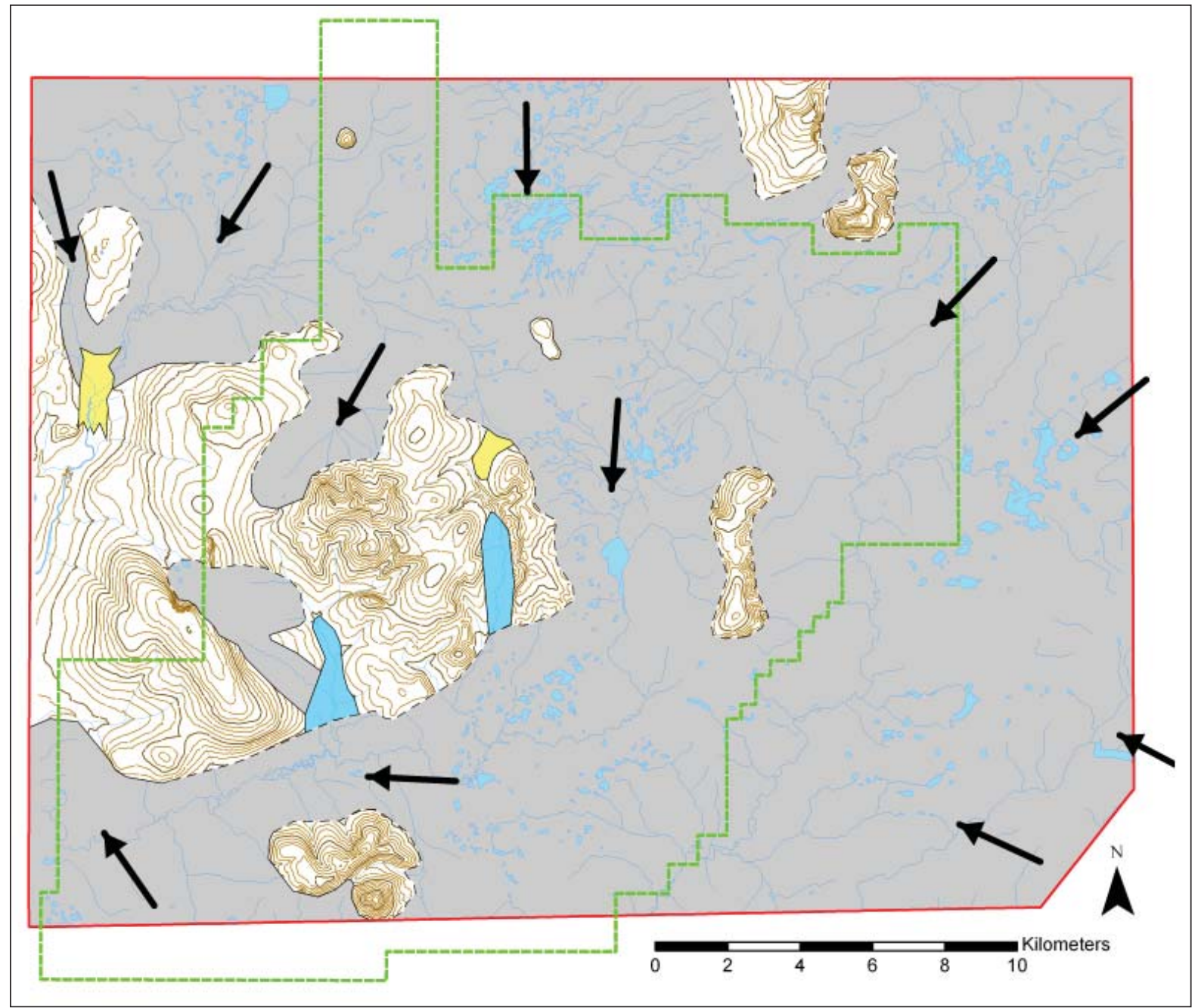

Figure 12. Inferred distribution in map area of glaciers (light gray), outwash (yellow), and glacial lakes (blue) during pre-Brooks Lake glaciation(s) (>30,000 ${ }^{14} \mathrm{C}$ yr BP). Unit boundaries dashed where speculative. Arrows show glacier flow directions.

massive end moraines deposited at the head of Koktuli River's North Fork during the preceding Kvichak stade. The southern lobe extended into a broad lake that filled the southwestern part of the map area. That lake may have been dammed by the huge Iliamna-age glacier that concurrently filled the basin of Iliamna Lake.

During the subsequent Newhalen stade, glaciers extended only short distances southwest and south of Lake Clark (Detterman and Reed, 1973). Two separate glaciers entered the eastern part of the map area, but extended into it for only short distances (fig. 15). An arcuate end moraine in the northeastern corner of the map area forms the drainage divide at the head of the eastern fork of Upper Talarik Creek. Another glacier entered the east-central part of the map area from the valley of the Newhalen River, but its end moraine and outwash are discontinuous. This glacier probably terminated in a glacial lake whose surface stood at about
240 to $260 \mathrm{~m}$ (800-850 ft) above sea level in that part of the map area, as defined by wave-cut notches, beach complexes, and deltas.

Unusual small kettle depressions and linear gravel deposits in the east-central part of the map area are attributed to large-magnitude outburst floods that were released from retreating glaciers in the Newhalen River area during waning phases of the Newhalen stade. Hundreds of small kettles of approximately equal size (figs. 16A and 16B) may have been formed by ice blocks carried by large floods issuing from the terminus or flank of a disintegrating glacier. Large asymmetric gravel deposits are aligned at right angles to inferred paleoflow directions (figs. 16C and 16D). The steeper flanks of these linear features face downflow; their gentler sloping flanks face upflow. These linear features are inferred to be transverse bars that developed as bedforms during 


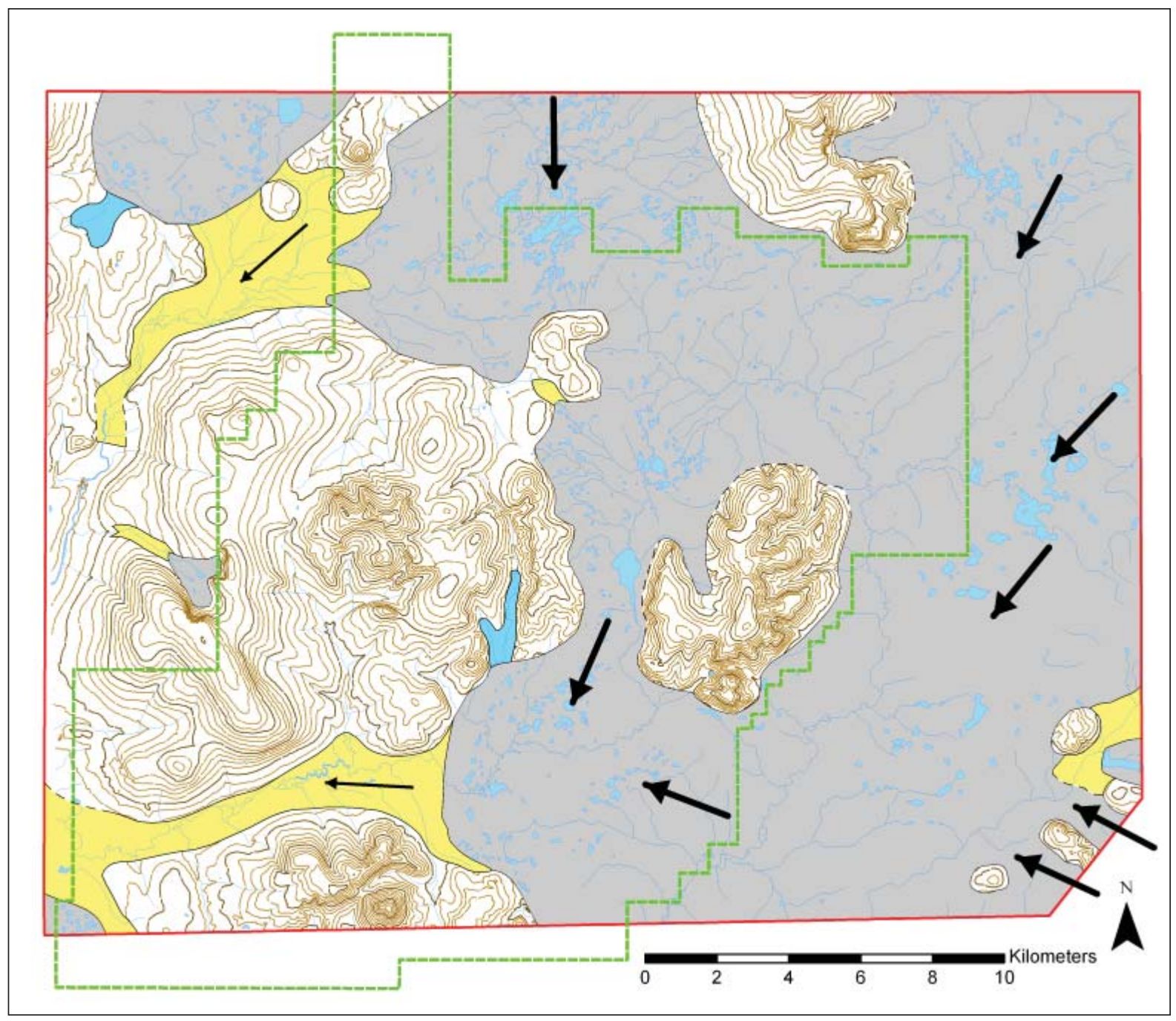

Figure 13. Distribution of glaciers and related features during Kvichak stade (ca. 26,000-18,000 ${ }^{14} \mathrm{C} \mathrm{yr} \mathrm{BP)} \mathrm{of}$ Brooks Lake glaciation. Colors as in figure 12. Thick arrows show glacier flow directions; slender arrows show directions of meltwater flow.

high-magnitude outburst floods. The field of small kettles and associated large-magnitude bedforms indicate that an unusual amount of meltwater surged southwestward from the retreating glacier of Newhalen age. Additional southwest-trending large meltwater channels farther south (shown on fig. 15) are present at and beyond the southeastern corner of the map area. This set of features suggests that meltwater from the Newhalen glacier did not flow directly into the basin of Iliamna Lake, but was blocked by a large mass of glacier ice that persisted there. The channels probably formed sequentially as the downwasting glacier uncovered new meltwater outlets at lower altitudes and progressively farther south. This relationship may indicate that the Newhalen stade, as defined along the Newhalen River, could overlap with waning phases of the Iliamna stade, as defined in the Iliamna Lake basin. The relation between these two inferred separate stades of the Brooks Lake glaciation requires reevaluation.

Although no radiocarbon dates could be obtained from the map area, broadly limiting dates elsewhere on the Alaska Peninsula and correlations with upper Cook Inlet have suggested that the Brooks Lake glaciation probably began about $26,000{ }^{14} \mathrm{C}$ yr BP and that its two oldest stades, Kvichak and Iliamna, may have terminated by about 16,500 to $16,000{ }^{14} \mathrm{C}$ yr BP. However, evidence presented above suggests that a large mass of glacier ice in the basin of Iliamna Lake may have persisted much longer. Glaciers during the subsequent Newhalen stade may have been at their maximum extent about 14,000 to $13,500 \mathrm{yr}$ BP. The final meltout of stagnating glacier ice in the map area and in the basin of Iliamna Lake may have required several thousand additional years, but it probably was complete by $10,000{ }^{14} \mathrm{C}$ yr BP. 


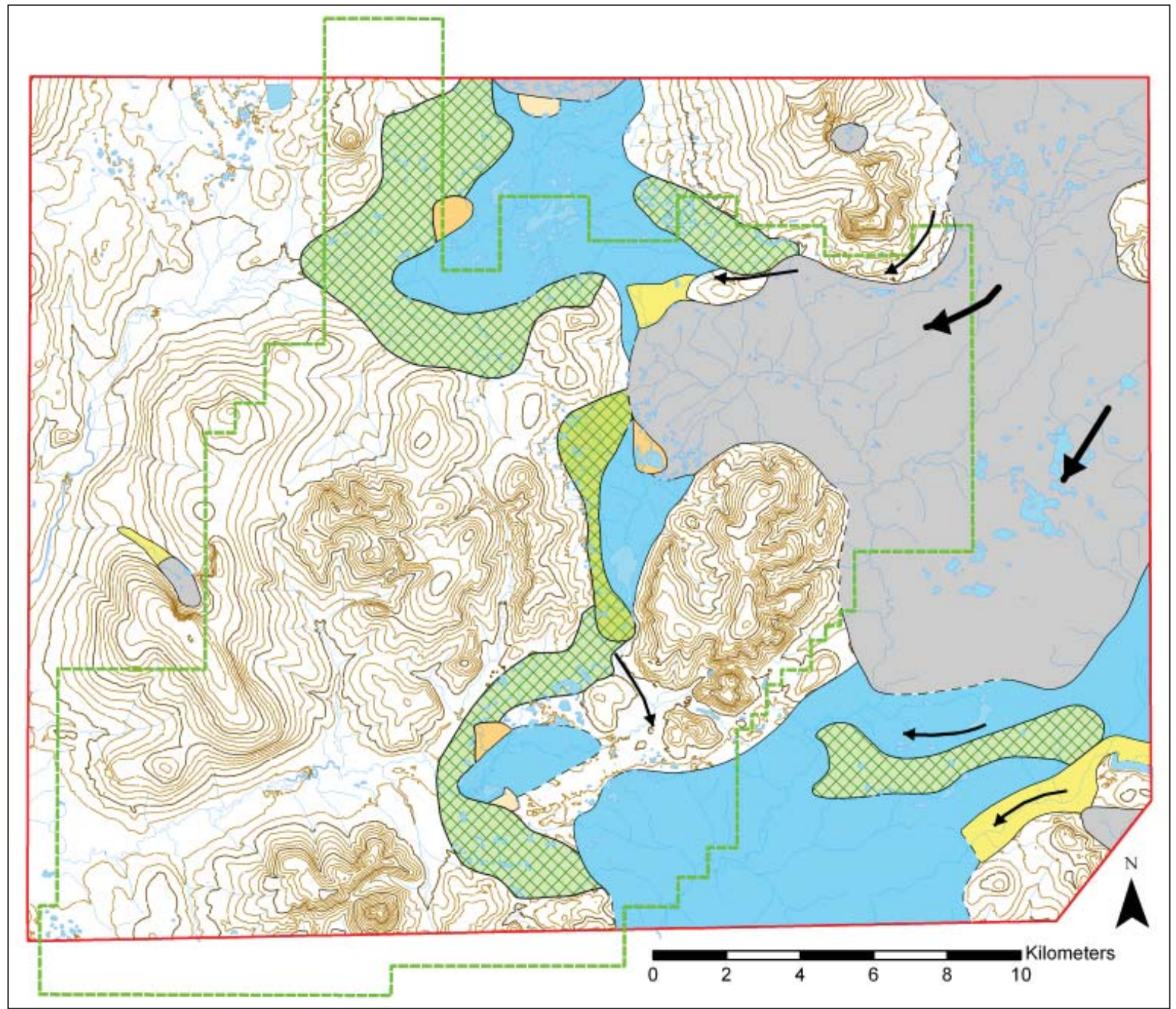

Figure 14. Distribution of glaciers and related features during Iliamna stade (ca. 18,000-16,000 ${ }^{14} \mathrm{C} \mathrm{yr} \mathrm{BP)} \mathrm{of}$ Brooks Lake glaciation. Colors and symbols as in figures 12 and 13. Moraine dams relict from Kvichak stade shown in green with cross-hatched pattern; delta and fan-delta deposits shown in orange.

\section{CONCLUSIONS}

1. The map area was impacted by glaciers from both the Aleutian Range (via Lake Clark trough) and lower Cook Inlet (via Iliamna Lake basin). Those glaciers entered this area from the north, northeast, southeast, and south.

2. End moraines formed present-day drainage divides in headwaters of the North and South Forks of Koktuli River, and at the head of Upper Talarik Creek. Extensive lakes were dammed behind the moraines; and ancient lake levels later were controlled by higher base levels in Iliamna Lake basin.

3. Moraines, glacial lakes, meltwater channels, and other glacial features formed repeatedly during suc- cessive glacial advances. Three glacial advances of Brooks Lake (late Wisconsin) age are distinguished, together with one or more pre-Brooks Lake advances.

4. Paleodrainage features, such as abandoned glacial drainageways and underfit channels, are widespread across the map area. Most are concordant with local terrain and former glaciers, but the southwesttrending channels that formed in east-central and southeastern parts of the map area during Newhalenstade deglaciation imply blockage by a persisting glacier in the basin of Iliamna Lake. The relation between the Iliamna and Newhalen stades of Brooks Lake glaciation should be reevaluated. 


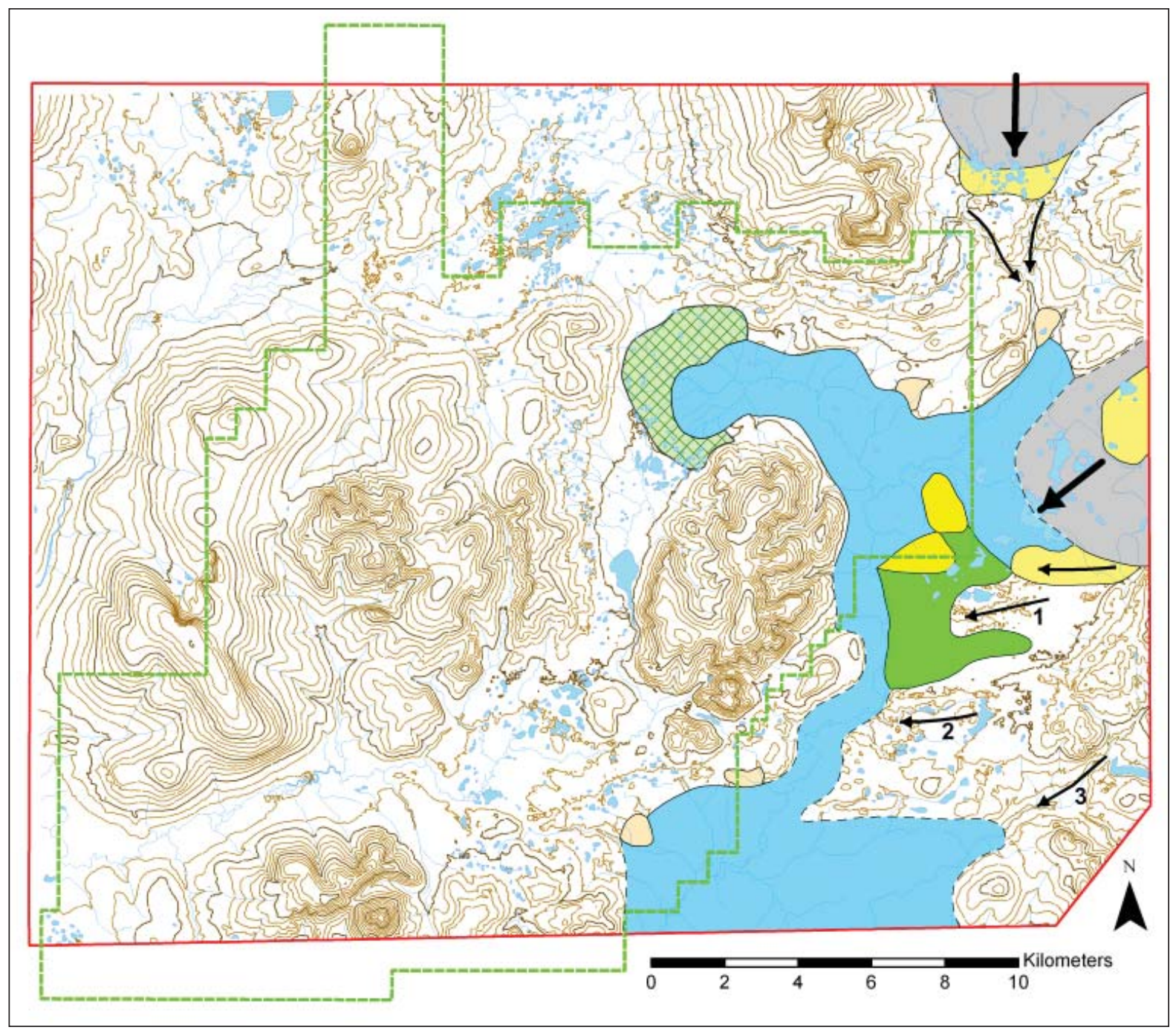

Figure 15. Distribution of glaciers and related features during Newhalen stade (ca. 14,000-13,000 ${ }^{14} \mathrm{C} \mathrm{yr} \mathrm{BP)} \mathrm{of}$ Brooks Lake glaciation. Colors and symbols as in figures 12-14. Ice-stagnation deposits shown in dark green. Numbered arrows in southeastern corner of map area show inferred sequential development of meltwater channels derived from glacial sources in Newhalen drainage system.

\section{ACKNOWLEDGMENTS}

Pebble Limited Partnership (Anchorage, AK) funded our surficial geologic mapping of the Pebble property and provided logistic support for our field work. We are especially grateful to Loretta Ford (Hunter Dickinson Inc., Vancouver, BC, Canada), who encouraged this project from the beginning and later facilitated publication of our map and report. Rod Smith (Schlumberger Water Services, Richmond, BC, Canada) recruited us to undertake mapping of the Pebble property to aid him in understanding its complex ground-water regime. Office facilities for preparing the map and technical assistance in assembling an earlier edition of the accompanying report (Hamilton, 2007) were furnished by SLR International Corp. (Anchorage, AK), with funding provided by Pebble Limited Partnership. We particularly wish to thank Scott Rose, SLR project manager, for his generous support and Kathy Riker for editorial assistance. Michael Anderson (Resource Data Inc., Anchorage, AK), digitized the maps that illustrate this report and the large folded map that accompanies it. His cartographic skills greatly enhanced the quality of those products.

Richard D. Reger (Reger's Geologic Consulting, Soldotna, Alaska) and Rodney A. Combellick (Alaska Division of Geological \& Geophysical Surveys) provided thorough and very helpful reviews that improved our map and report significantly. The map and report also benefited from the editorial skills, respectively, of De Anne Stevens and Paula Davis, and the design and layout expertise of Joni Robinson, all members of Alaska's Division of Geological \& Geophysical Surveys. 

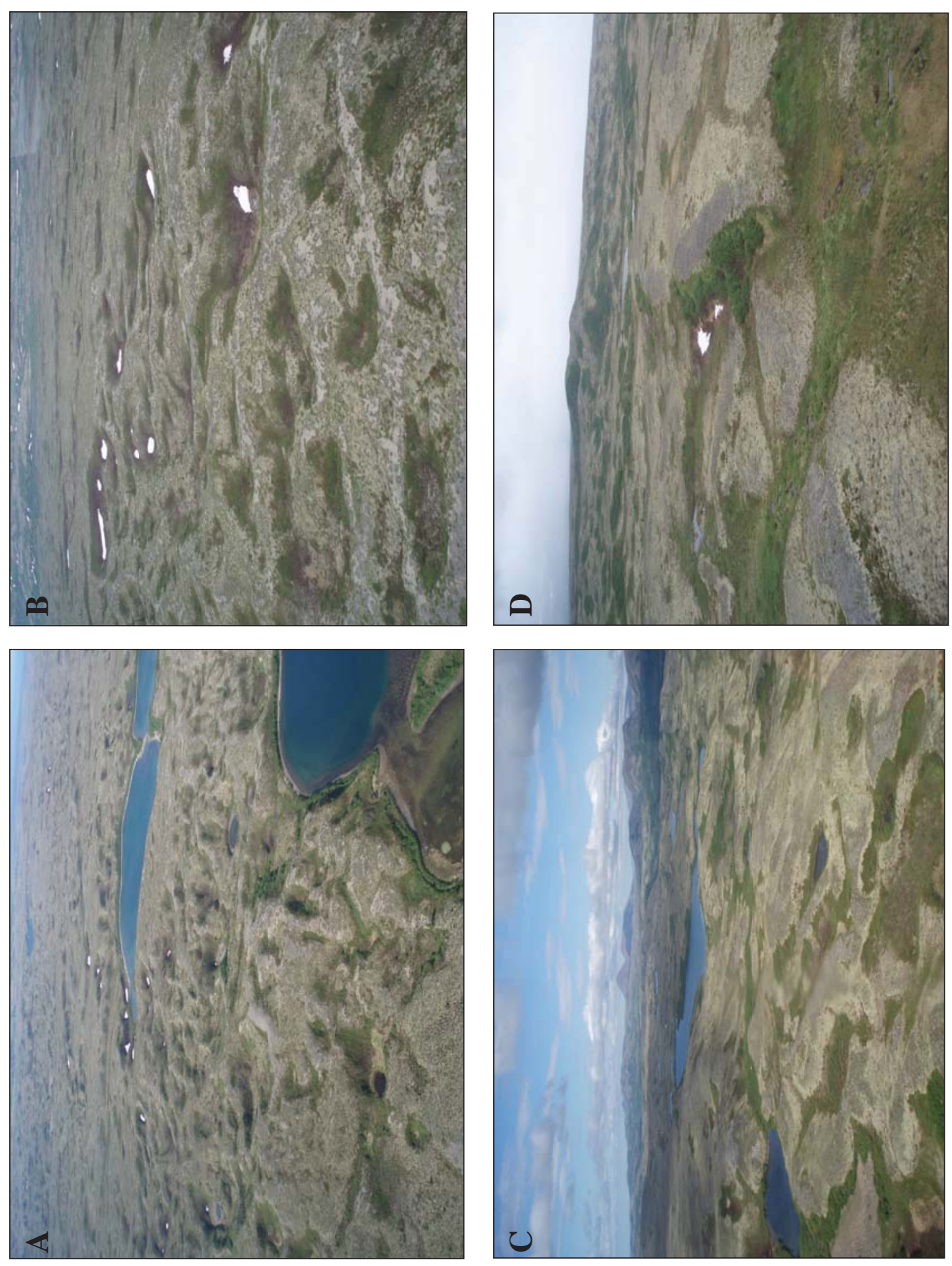

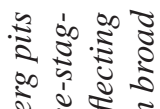

ปั

. 52

응

응 क्ष

है जे

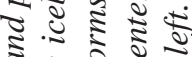

원웡

吾范

๘

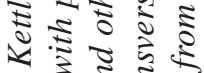

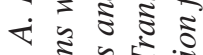

๘ँ

பั

ई की के

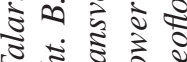

ㄷำ

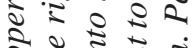

ईิ)

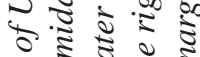

苛

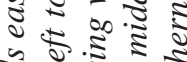

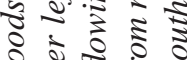

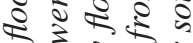

के के

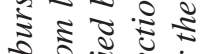

ปิ

ริ ฐิ

可

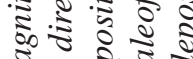

3 :

ㅎำ

$: \stackrel{2}{2}: 3$

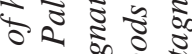

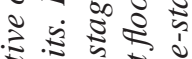

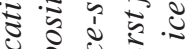

:

ปับ

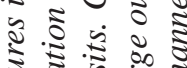

इ :

के क्षे के

$\dot{0}: \approx$

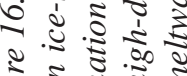

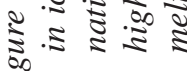


We are grateful to Pebble Limited Partnership for making our map and report freely available, first as a widely distributed internal document (Hamilton, 2007), then as a public Data Release (Pebble Limited Partnership, 2008), and finally as this publication.

\section{REFERENCES CITED}

Brown, J., Ferrians, O.J., Jr., Heginbottom, J.A., and Melnikov, E.S., 1997, Circum-Arctic map of permafrost and ground-ice conditions: U.S. Geological Survey Circum-Pacific Map Series CP-45, 1 sheet, scale 1:10,000,000.

Detterman, R.L., 1986, Glaciation of the Alaska Peninsula, in Hamilton, T.D., Reed, K.M., and Thorson, R.M., eds., Glaciation in Alaska-The geologic record: Anchorage, Alaska Geological Society, p. 151-170.

Detterman, R.L. and Reed, B.L., 1973, Surficial deposits of the Iliamna quadrangle, Alaska: U.S. Geological Survey Bulletin 1368-A, p. A-1-A-64.

Detterman, R.L., Hudson, Travis, Plafker, George, Tysdal, R.G., and Hoare, J.M., 1976, Reconnaissance geologic map along Bruin Bay and Lake Clark faults in Kenai and Tyonek quadrangles, Alaska: U.S. Geological Survey Open-File Report 76-477, 1 sheet, scale 1:250,000, 4 p.

Ferrians, O.J., Jr., 1965, Permafrost map of Alaska: U.S. Geological Survey Miscellaneous Geologic Investigations Map I-445, 1 sheet, scale 1:2,500,000.

Hamilton, T.D., 2007, Surficial geologic map of the Pebble Limited Partnership's Pebble Project: Anchorage, Alaska, Pebble Limited Partnership, unpublished map and report, 1 sheet, scale 1:50,000, 9 p.

Kaufman, D.S., and Stilwell, K.B., 1997, Preliminary evaluation of emergent postglacial shorelines, Naknek and Iliamna Lakes, southwestern Alaska, in Doumoulin, J.A., and Gray, J.E., eds., Geologic Studies in Alaska by the U.S. Geological Survey, 1995: U.S. Geological Survey Professional Paper 1574, p. 73-81.

Kaufman, D.S., and others, 2004, Holocene thermal maximum in the western Arctic $\left(0-180^{\circ} \mathrm{W}\right)$ : Quaternary Science Reviews, v. 23, p. 529-560.

Lea, P.D., 1990, Pleistocene periglacial eolian deposits in southwestern Alaska: Sedimentary facies and depositional processes: Journal of Sedimentary Petrology, v. 60, p. 582-591.

Mann, D.H., and Peteet, D.M., 1994, Extent and timing of the last glacial maximum in southwestern Alaska: Quaternary Research, v. 42, p. 136-148.
Muller, E.H., 1953, Northern Alaska Peninsula and eastern Kilbuck Mountains, Alaska, in Péwé, T.L., and others, Multiple glaciation in Alaska, a progress report: U.S. Geological Survey Circular 289, p. 2-3.

Pebble Limited Partnership, 2008, Report Series C-Surficial Geology: Anchorage, Alaska, Pebble Limited Partnership Pre-Permitting Environmental/ Socio-Economic Data Report Series, 2 p.

Pinney, D.S., and Begét, J.E., 1991, Late Pleistocene volcanic deposits near the Valley of Ten Thousand Smokes, Katmai National Park, Alaska, in Reger, R.D., ed., Short Notes on Alaskan Geology 1991: Alaska Division of Geological \& Geophysical Surveys Professional Report 111, p. 45-54.

Reger, R.D., and Pinney, D.S., 1997, Last major glaciation of Kenai Lowland, in Karl, S.M., Vaughn, N.R., and Ryherd, T.J., eds., 1997 guide to the geology of the Kenai Peninsula, Alaska: Anchorage, Alaska Geological Society, p. 54-67.

Reger, R.D., Combellick, R.A., and Brigham-Grette, Julie, 1995, Late-Wisconsin events in the upper Cook Inlet region, south-central Alaska, in Combellick, R.A., and Tannian, Fran, eds., Short Notes on Alaskan Geology, 1995: Alaska Division of Geological \& Geophysical Surveys Professional Report 117, p. 33-45.

Reger, R.D., Sturmann, A.G., Berg, E.E., and Burns, P.A.C., 2007, A guide to the late Quaternary history of northern and western Kenai Peninsula, Alaska: Alaska Division of Geological \& Geophysical Surveys Guidebook 8, 112 p, 6 sheets, scale 1:63,360.

Riehle, J.R., Ager, T.A., Reger, R.D., Pinney, D.S., and Kaufman, D.S., 2008, Stratigraphic and compositional complexities of the late Quaternary Lethe tephra in south-central Alaska: Quaternary International, v. 178, p. 210-228.

Schmoll, H.R., Szabo, B.J., Rubin, Meyer, and Dobrovolny, Ernest, 1972, Radiometric dating of marine shells from the Bootlegger Cove Clay, Anchorage area, Alaska: Geological Society of America Bulletin, v. 83, p. 1,107-1,113.

Stilwell, K.B., 1995, Late Quaternary glacial geology, shoreline morphology, and tephrochronology of the Iliamna/Naknek/Brooks Lake area, southwestern Alaska: Logan, Utah, Utah State University M.S. thesis, $145 \mathrm{p}$.

Stilwell, K.B., and Kaufman, D.S., 1996, Late-Wisconsin glacial history of the northern Alaska Peninsula, southwestern Alaska, U.S.A.: Arctic and Alpine Research, v. 28, p. 475-487. 